\title{
Cyclohexane oxidative dehydrogenation over copper oxide catalysts
}

\author{
Scott L. Nauert ${ }^{1}$, Fabian Schax ${ }^{2}$, Christian Limberg ${ }^{2}$, Justin M. Notestein ${ }^{1, *}$ \\ ${ }^{1}$ Northwestern University, Department of Chemical and Biological Engineering, \\ 2145 Sheridan Road, Technological Institute E136, Evanston, IL 60208, USA \\ ${ }^{2}$ Humboldt-Universität zu Berlin, Institut für Chemie, Berlin, Germany \\ *i-notestein@northwestern.edu \\ 847.491.5357 (phone) \\ 847.491 .3728 (fax)
}

\begin{abstract}
Here, we report on structure-reactivity trends for cyclohexane oxidative dehydrogenation (ODH) with silica supported copper oxide catalysts as a function of surface structure. Copper oxide was supported on mesostructured KIT- 6 silica at low surface densities $<0.2 \mathrm{Cu} / \mathrm{nm}^{2}$ using copper (II) nitrate, ammonium and sodium copper (II) ethylenediaminetetraacetate, and a hexanuclear copper (I) siloxide complex. Copper oxide surface structures were characterized by X-ray absorption spectroscopy as well as ambient and in situ diffuse reflectance UV-visible (DRUV-vis) spectroscopy to determine trends in copper oxide nuclearity. DRUV-vis spectroscopy identifies three copper species based on $\mathrm{Cu}^{2+}$ ligand to metal transfer (LMCT) bands at 238, 266, and $>300 \mathrm{~nm}$ as well as $\mathrm{Cu}^{+} \mathrm{LMCT}$ bands at 235, 296, and 312 $\mathrm{nm}$. Counterintuitively, EXAFS analysis shows that the multinuclear precursor leads to fewer average $\mathrm{Cu}$ $\mathrm{Cu}$ interactions than syntheses with mononuclear copper salt precursors. Turnover frequency and selectivity to benzene increase with decreasing copper oxide nuclearity, and thus the multinuclear precursor leads to the highest turnover frequency and benzene production. This work shows the variety of surface species that exist even at extremely low copper surface densities, control of which can improve reactivity of an atypical ODH catalyst up to rates comparable to benchmark vanadia catalysts.
\end{abstract}

\section{Keywords}

Oxidative dehydrogenation; Copper oxide; Cyclohexane; KIT-6 


\section{Introduction}

Oxidative dehydrogenation (ODH) of alkanes is a promising route for producing valuable commodity chemicals such as propylene. The production of $\mathrm{H}_{2} \mathrm{O}$ instead of $\mathrm{H}_{2}$ makes ODH an exothermic reaction, and therefore $\mathrm{ODH}$ processes can operate at lower temperatures and pressures than endothermic non-oxidative routes, while not being limited by a low maximum equilibrium production of olefins. ODH processes also have the advantage that oxygen present in the feed stream helps prevent catalyst deactivation by coking. ODH processes are limited to low single-pass conversions to limit over oxidation of products to $\mathrm{CO}_{\mathrm{x}}$. A major goal in alkane $\mathrm{ODH}$ is therefore to determine and control the catalyst structural properties that lead to high selectivity to olefins without over-oxidation.

Alkane $\mathrm{ODH}$ has been extensively studied over supported $\mathrm{VO}_{\mathrm{x}}$ catalysts[1-6] as well as reported

over other reducible oxides such as $\mathrm{Co}_{3} \mathrm{O}_{4[7]}, \mathrm{MoO}_{3}[5,8], \mathrm{WO}_{3}[5]$, and $\mathrm{MgVO}_{\mathrm{x}}[9-12]$. Grabowski et al.[13] and more recently Carrero et al.[14] have compiled kinetic data from more than 100 examples of supported $\mathrm{VO}_{\mathrm{x}}$ and other reducible metal oxides and found that alkane ODH occurs by a Mars van Krevelan redox mechanism with rate limiting initial $\mathrm{C}-\mathrm{H}$ bond activation. This is supported by isotopic studies[6] as well as kinetic studies showing a zero order dependence on oxygen partial pressure along with a positive order dependence on alkane partial pressure $[2,5] . \mathrm{CO}_{x}$ is formed primarily by consecutive oxidation of the alkene with $\mathrm{C}-\mathrm{C}$ bond scission, and to a lesser extent by direct oxidation of the alkane[2, 4, 5, 13].

While ODH activity and reaction pathway has been established with a variety of supported reducible oxide catalysts, there is still a major question as to how oxide structure influences ODH activity and selectivity. Dispersed oxide catalysts lend themselves to a distribution of different surface structures with varying numbers of metal-oxygen-support and metal-oxygen-metal bonds as well as the possibility of bulk crystalline phases even at low metal surface densities. These different structures may have different rates of $\mathrm{C}-\mathrm{H}$ and $\mathrm{C}-\mathrm{C}$ bond activation, which affects $\mathrm{ODH}$ activity and selectivity. Reports of ODH over vanadia agree that crystalline $\mathrm{V}_{2} \mathrm{O}_{5}$ leads entirely to combustion products while sub-monolayer $\mathrm{VO}_{\mathrm{x}}$ structures produce both olefins and $\mathrm{CO}_{\mathrm{x}}[14]$. However, they disagree on whether activity and selectivity are a function of the nuclearity of sub-monolayer structures on a per exposed metal basis. Studies comparing TOF as a function of metal surface density with $\mathrm{SiO}_{2}$ supported $\mathrm{VO}_{\mathrm{x}}$ catalysts report conflicting messages that TOF decreases $[15,16]$, increases $[3,17]$, or stays constant[18, 19] over a range of $V$ surface densities. Surface density alone serves as a poor proxy for surface structure nuclearity which is heavily influenced by synthetic method[14]. A more direct comparison between surface structure and reactivity is required to separate catalyst qualities which lead to selective $\mathrm{ODH}$ vs. those leading to $\mathrm{C}-\mathrm{C}$ scission and $\mathrm{CO}_{x}$.

Cyclohexane $\mathrm{ODH}$ is an excellent model reaction for studying structural effects on alkane ODH reactivity[4]. Unlike with propane, all $\mathrm{C}-\mathrm{C}$ and $\mathrm{C}-\mathrm{H}$ bonds are equivalent, which simplifies reaction kinetics. Moreover, breaking multiple $\mathrm{C}-\mathrm{H}$ bonds leads to benzene rather than $\mathrm{CO}_{\mathrm{x}}$ like with propane. This allows for separating catalysts' propensity for desired $\mathrm{C}-\mathrm{H}$ vs. undesired $\mathrm{C}-\mathrm{C}$ bond scission.

Here, we describe and investigate a new catalyst for cyclohexane ODH consisting of silicasupported copper oxide. Highly dispersed copper(II) oxide should be a promising candidate for cyclohexane $\mathrm{ODH}$. Copper structures are well known for activating $\mathrm{O}_{2}$ in enzymes and biomimetic zeolite catalysts[20-22], and $\mathrm{CuO}$ nanoclusters and highly dispersed $\mathrm{Cu}^{2+}$ show remarkable activity 
towards cyclohexane oxidation to cyclohexanone and cyclohexanol with molecular oxygen in high pressure batch systems[23-26]. This suggests it should be a good candidate for breaking $\mathrm{C}-\mathrm{H}$ bonds without $\mathrm{C}-\mathrm{C}$ bond scission, which is required for cyclohexane $\mathrm{ODH}$. However, there have been virtually no reports of $\mathrm{Cu}$-catalyzed $\mathrm{ODH}$. $\mathrm{Cu}^{2+}$ doped strontium hydroxyapatite shows high olefin selectivity for propane $\mathrm{ODH}\left[27\right.$ ] compared with non-doped materials, but in that case, the structure of $\mathrm{Cu}^{2+}$ in the catalyst is not well understood. In another case, crystalline CuO powder showed up to $85 \%$ selectivity to propene in the presence of tetrachloromethane under $\mathrm{O}_{2}$ limiting conditions, but the selectivity switched to $>90 \%$ combustion products when tetrachloromethane was not added to the feed[28]. This parallels vanadia catalysts in that bulk crystallites exclusively catalyze combustion rather than selective $\mathrm{ODH}$.

Here, we report on structure-reactivity trends for cyclohexane ODH with copper oxide catalysts as a function of surface structure nuclearity. We have synthesized a series of materials consisting of copper oxide supported on mesostructured KIT-6 silica with varying Cu precursors and copper loadings. In particular, a multinuclear copper siloxide cluster, denoted $\mathrm{L}_{2} \mathrm{Cu}_{6}$, was utilized as one of the precursors[29] with the goal of synthesizing small clusters. Scheme 1 shows the $\mathrm{L}_{2} \mathrm{Cu}_{6}$ cluster consists of a hexanuclear $\mathrm{Cu}^{+}$core bound by two tripodal siloxide ligands which are robust and fix the cluster during impregnation, at the same time already providing a mimic of the support environment. In addition, the steric bulk of the siloxide ligands should ensure copper clusters do not aggregate during synthesis of the catalyst. Overall, the different precursors and loadings are intended to generate materials with differing average copper nuclearity, from isolated $\mathrm{Cu}^{2+}$ monomers to extended $\mathrm{Cu}^{2+}$ aggregates, as illustrated in scheme 2. These materials were characterized by $\mathrm{N}_{2}$ physisorption, $X$-ray diffraction (XRD), X-ray absorption near-edge structure (XANES), extended X-ray absorption fine structure (EXAFS), and diffuse reflectance UV-visible (DRUV-vis) spectroscopy under ambient and reducing conditions to determine trends in average copper oxide nuclearity. Their reactivity towards cyclohexane ODH is then evaluated to demonstrate how copper oxide structure influences $\mathrm{ODH}$ activity and selectivity.

\section{Experimental Methods}

\subsection{Materials synthesis}

KIT-6 mesostructured silica was synthesized using a precipitation method adapted from Ryoo et al.[30] using a molar ratio of $195 \mathrm{H} 20: 1.5 \mathrm{~mol}$ tetraethyl orthosilicate (TEOS) : $1.7 \mathrm{n}$-butanol : $1.83 \mathrm{HCl}$ : 0.017 Pluronic ${ }^{\circledast}$ P-123 (Sigma, $M_{n}=5800 \mathrm{~g} / \mathrm{mol}$ ). Briefly, $17.3 \mathrm{~g}$ of $37 \mathrm{wt} \%$ aqueous hydrochloric acid (Fischer, ACS grade) and $9.6 \mathrm{~g}$ of Pluronic ${ }^{\circledR} \mathrm{P}-123$ were added to $326 \mathrm{~mL}$ de-ionized water and stirred at $750 \mathrm{rpm}$ at $308 \mathrm{~K}$ for $4 \mathrm{~h}$ until complete dissolution of the P-123 polymer. Next, $12.15 \mathrm{~g} \mathrm{n}$-butanol (Sigma, 99.0\%) was added to the mixture and stirred for $1 \mathrm{~h}$. Then $30.2 \mathrm{~g}$ TEOS (Sigma, 99.0\%) was added, and the mixture was stirred for an additional $24 \mathrm{~h}$. The mixture was subsequently aged at $373 \mathrm{~K}$ for $24 \mathrm{~h}$ under reflux without stirring. The white precipitate was filtered hot, washed with ethanol and water, and dried at $373 \mathrm{~K}$ for $16 \mathrm{~h}$. The dried powder was calcined at $823 \mathrm{~K}$ for $4 \mathrm{~h}$ with a $5 \mathrm{~K} / \mathrm{min}$ ramp rate before use.

Copper oxide catalysts were prepared by incipient wetness impregnation of KIT- 6 supports and are denoted by metal weight loading followed by precursor used. KIT- 6 was dried at $493 \mathrm{~K}$ under dynamic vacuum for $16 \mathrm{~h}$ prior to use for all catalysts. The dried support was then impregnated with 
aqueous solutions of $\mathrm{Cu}\left(\mathrm{NO}_{3}\right)_{2} \cdot 3 \mathrm{H}_{2} \mathrm{O}$ (Strem, 99.5\%), $\mathrm{Na}_{2} \mathrm{CuEDTA}$ (Sigma, 97.0\%), or $\left(\mathrm{NH}_{4}\right)_{2} \mathrm{CuEDTA}$. The complex $\left(\mathrm{NH}_{4}\right)_{2}$ CuEDTA was synthesized following an established procedure[31] and purified by crystallization in methanol. A hexanuclear $\mathrm{Cu}(\mathrm{I})$ complex with two tripodal, trisilanol ligands, denoted $\mathrm{L}_{2} \mathrm{Cu}_{6}$, was synthesized according to a procedure by Limberg et al.[29] $\mathrm{L}_{2} \mathrm{Cu}_{6}$ catalysts were prepared by impregnating dried $\mathrm{KIT}-6$ with $\mathrm{L}_{2} \mathrm{Cu}_{6}$ dissolved in THF under oxygen- and moisture-free conditions and let dry for $24 \mathrm{~h}$ at room temperature in an argon-filled glove box. THF was prepared by distillation over $\mathrm{Na}-$ benzophenone followed by three freeze pump thaw cycles to remove water and dissolved gasses. The $\mathrm{L}_{2} \mathrm{Cu}_{6}$ catalysts were then dried for an additional $24 \mathrm{~h}$ at room temperature under dynamic vacuum before exposure to air to remove additional physisorbed solvent. Note that $\mathrm{L}_{2} \mathrm{Cu}_{6}$ is sparingly soluble in many solvents, and that its comparatively high solubility in THF limits the amount of Cu deposition possible in a single round of incipient wetness impregnation.A vanadia catalyst was prepared by a grafting procedure adapted from Du et al[32]. First, $0.0823 \mathrm{~g} \mathrm{VCl}_{3} \cdot 3 \mathrm{THF}$ (Strem) was suspended in 130 $\mathrm{mL}$ dry toluene under $\mathrm{N}_{2}$ atmosphere forming an orange solution. Next, $20 \mathrm{~mL}$ ethanol was added at which point the solution turned light green. Excess ethanol was distilled out of the solution at $383 \mathrm{~K}$ at which point $1 \mathrm{~g} \mathrm{KIT-6}$ support suspended in toluene was added to solution. The solution was refluxed at $383 \mathrm{~K}$ for $24 \mathrm{~h}$, filtered, washed with $150 \mathrm{~mL}$ toluene, and dried overnight. All catalysts were then calcined at $823 \mathrm{~K}$ for $4 \mathrm{hr}$ with a $5 \mathrm{~K} / \mathrm{min}$ ramp rate, with the exception of the $\mathrm{L}_{2} \mathrm{Cu}_{6}$ catalyst, which was left as synthesized.

\subsection{Catalyst characterization}

Nitrogen adsorption-desorption isotherms were collected using a Micromeritics ASAP 2010 instrument. Prior to measurement, samples were degassed at $473 \mathrm{~K}$ under dynamic vacuum until pressure stabilized at $5 \times 10^{-6}$ bar, typically $8-16 \mathrm{~h}$. The surface area of the samples was calculated from the adsorption isotherm using the BET method, while mesopore size distribution and volume was calculated from the desorption isotherm using the Barrett-Joyner-Halenda (BJH) method. The metal content was determined using ICP-OES (Thermo iCAP 7600) calibrated with $\mathrm{Cu}$ and $\mathrm{V}$ standards of known concentration. Samples were digested with $48 \mathrm{wt} \% \mathrm{HF}$ then diluted ten-fold with $0.9 \mathrm{wt} \% \mathrm{HNO}_{3}$ and shaken at $300 \mathrm{rpm}$ at room temperature for $24 \mathrm{~h}$ prior to analysis. X-ray diffraction (XRD) spectra were collected using a Rigaku ATXG X-ray diffractometer over the range $1-3^{\circ} 2 \theta$ for KIT- 6 diffraction patterns and $20-80^{\circ} 2 \theta$ for $\mathrm{CuO}$ diffraction patterns, using $\mathrm{Cu} \mathrm{K} \alpha$ radiation. Thermogravimetric analysis with mass spectrometer (TGA-MS) were conducted on a TA Instruments TGA Q500 attached to a Pfeiffer ThermoStar $301 \mathrm{~T}$ mass spectrometer in high-resolution mode with a $10 \mathrm{~K} / \mathrm{min}$ ramp up to $873 \mathrm{~K}$ under a flow of dry synthetic air. Temperature programmed reduction experiments were performed on an Altamira AMI-2000 chemisorption instrument in the CleanCat user facility at Northwestern University.

Diffuse reflectance UV-visible spectra were collected with a Shimadzu UV-3600 spectrophotometer equipped with a Harrick Praying Mantis diffuse reflectance accessory and reaction cell for in situ measurements. Polytetrafluoroethylene was used as the baseline white standard, and reflectance data were transformed to pseudo-absorbance using the Kubelka-Munk function, $F\left(R_{\infty}\right)$, using the KIT-6 support as the reference as in equations 1 and 2 .

$$
\mathrm{R}_{\infty}=\frac{\mathrm{R}_{\text {sample }}}{\mathrm{R}_{\mathrm{KIT} 6}}
$$

Eq. 1 


$$
F\left(R_{\infty}\right)=\frac{\left(1-R_{\infty}\right)^{2}}{2 R_{\infty}} \propto \frac{\alpha(\text { absorption coefficient })}{S \text { (scattering coefficient })}
$$

Eq. 2

All samples are diluted with KIT-6 support to achieve similar $F\left(R_{\infty}\right)<1.5$ to avoid non-linearity issues in the Kubelka-Munk transformation for highly absorbing samples. Pseudo-absorbance spectra are treated with a Savitzky-Golay filter with polynomial degree 2 and 11 point frame to increase signal to noise ratio at the expense of minor signal distortion. Absorption edge energies are estimated from the $x$-intercept of a linear fit of the rising absorption edge in a plot of $\left(F\left(R_{\infty}\right) h v\right)^{1 / n}$ where $n=1 / 2$ for direct allowed transitions as in copper oxide catalysts and $n=2$ for indirect allowed transitions as in the vanadia catalyst.

Cu K-edge X-ray absorption spectroscopy (XAS) was performed at Sector 5 of the Advanced Photon Source, Argonne National Laboratory, on the Dupont-Northwestern-Dow Collaborative Access Team (DND-CAT) bending magnet $D$ beamline. The beam energy was controlled by a Si(111) monochromator with resolution $\Delta \mathrm{E} / \mathrm{E} \approx 1.3 \times 10^{-4} \mathrm{eV}$. Incident and transmitted intensities were measured with Canberra ionization chambers while fluorescence measurements were measured using a fourchannel SII Vortex-ME4 detector. Energies were calibrated in transmission mode against a Cu foil, setting the first inflection point at the known Cu edge energy of $8979 \mathrm{eV}$. Dried Cu catalysts were pressed into $0.05 \mathrm{~g}$ pellets under oxygen and moisture free conditions and mounted into a 9-pellet controlled atmosphere cell with flowing $\mathrm{N}_{2}$. Catalysts were mounted at an incident angle of $\theta=45 \pm 5^{\circ}$ with respect to the beam and fluorescence detectors, and spectra were collected in fluorescence mode. For EXAFS analysis, XAS spectra were normalized in Athena and background removed using the AUTOBK algorithm. The Fourier transform was computed over the wavenumber range $k=3.0-10.0 \AA^{-1}$ using a Hanning window function with width $d k=0.5 \AA^{-1}$, and fits to the EXAFS function were computed using the real and imaginary components of the Fourier transformed $k^{2}$-weighted $\chi(k)$ function over the range $R=1.0-3.0 \AA$ giving a total of 8.91 independent points by the Nyquist criterion. The manybody amplitude reduction factor, $S_{0}^{2}$, was set to 0.8 for all fits. The first two coordination shells were fit using $\mathrm{Cu}-\mathrm{O}$ and $\mathrm{Cu}-\mathrm{Cu}$ scattering paths generated from $\mathrm{CuO}$ crystallographic data using FEFF 6.0. Real and imaginary components of the forward Fourier transform of the $k^{2}$-weighted $\chi$ function as well as model fits are given in figure S1. The Debye-Waller factor and coordination number are typically highly correlated for any scattering path. To determine model sensitivity, $\mathrm{Cu}-\mathrm{O}$ and $\mathrm{Cu}-\mathrm{Cu}$ coordination numbers were varied while maintaining an R-factor model error within $20 \%$ of the error of the best fit model.

\subsection{Measurements of catalytic activity}

Catalytic measurements were conducted in a packed-bed quartz microreactor using 0.01-0.1 g catalyst diluted with KIT- 6 support to a total bed mass of $0.1 \mathrm{~g}$ to ensure similar flow characteristics. Bed heights measured 3-5 mm in height to minimize pressure and temperature gradients. He (Airgas, 99.999\%) and $\mathrm{O}_{2}$ (Airgas, 99.999\%) flows were supplied by mass flow controllers. Cyclohexane was supplied by bubbling He through a cyclohexane saturator with a fixed pressure of 1.44 bar and fixed temperature $296 \mathrm{~K}$ to achieve a known cyclohexane molar flow rate. Reactions were performed using a cyclohexane: $\mathrm{O}_{2}$ : He molar composition of 1: 4.7: 94.3 with a total flow rate of $31.6 \mu \mathrm{mol} / \mathrm{s}$. All lines were heated to $363 \mathrm{~K}$ to avoid condensation of vapors. Catalysts were dried in a $5 \% \mathrm{O}_{2}$ in $\mathrm{He}$ stream at $523 \mathrm{~K}$ for $1 \mathrm{~h}$ prior to reaction, and reactions were carried out at atmospheric pressure over the 
temperature range 523-623 K. Products were analyzed using an Agilent GC 6890 with capillary column (HP-Innowax, $30 \mathrm{~m} \times 320 \mu \mathrm{m} \times 0.5 \mu \mathrm{m}$ ) and flame ionization detector (FID). Conversion was measured relative to the cyclohexane detected when the flow bypassed the reactor and was maintained below $2 \%$ in all catalytic tests and all temperatures. Negligible cyclohexane conversion was observed up to $623 \mathrm{~K}$ with a blank reactor or with $0.1 \mathrm{~g}$ KIT- 6 support. Mass balance is defined with respect to carbon as the sum of $\mathrm{C}_{6}$ species detected during a reaction divided by the sum of cyclohexane detected when the flow bypassed the reactor, and mass balances measured $98 \pm 5 \%$ for all reactions at all temperatures. ODH selectivity is reported as:

$$
\mathrm{S}_{\text {Benzene }}=\frac{\text { Benzene rate }}{\text { Cyclohexene+Benzene rate }} \quad \text { Eq. } 3
$$

\section{Results}

\subsection{Support and catalyst characterization by nitrogen physisorption}

KIT-6 mesoporous silica was used as the catalyst support instead of other mesostructured silicas, in part because its open pore geometry and narrow mesopore size distribution make it ideal for impregnating bulky precursors such as $\mathrm{L}_{2} \mathrm{Cu}_{6}$. Small angle powder XRD shows the (211) and (220) peaks characteristic of KIT-6's Ia $\overline{3} d$ pore structure[30] (Fig. S2). Table 1 shows characterization results of catalysts and their KIT-6 supports. Surface areas varied batch to batch from 800-1000 m²/g, and all KIT-6 used has mesopore diameters of $5.2 \pm 0.2 \mathrm{~nm}$ large enough to accommodate the $\mathrm{L}_{2} \mathrm{Cu}_{6}$ precursor with a diameter of $\sim 2 \mathrm{~nm}$. Mesopore volume decreased roughly 10\% upon impregnation and calcination which confirms the pore structure is stable after calcination up to $823 \mathrm{~K}$. This pore volume decrease is less than the $25-35 \%$ pore volume decrease typical for SBA-15 supported catalysts $[4,33,34]$ and is attributed to the open pore geometry of KIT-6.

Catalyst metal loadings in table 1 were determined by ICP-OES and used to calculate metal surface density. All catalysts have a low surface density of $0.12 \mathrm{Cu} / \mathrm{nm}^{2}$ for $1.4-\mathrm{Cu}\left(\mathrm{NO}_{3}\right)_{2}$ and $0.014 \pm 0.002$ $\mathrm{Cu} / \mathrm{nm}^{2}$ for $0.14 \mathrm{wt} \% \mathrm{Cu}$ catalysts. Even the highest loading is $<2 \%$ of the reported $6.5 \mathrm{Cu} / \mathrm{nm}^{2}$ geometric monolayer coverage[35], and $\mathrm{Cu}$ ions are statistically likely to be isolated. However, studies on several supported metal oxides show that catalysts with coverage well below a statistical monolayer may possess a range of non-isolated structures[36, 37] as well as bulk metal oxide crystallites. In particular, oligomeric and bulk crystalline $\mathrm{CuO}$ were identified in MCM-41 supported copper oxide catalysts with copper surface densities as low as $0.05 \mathrm{Cu} / \mathrm{nm}^{2}[38,39]$. Powder XRD, figure $\mathrm{S} 3$, shows no diffraction lines associated with $\mathrm{CuO}$, which indicates the absence of bulk $\mathrm{CuO}$ crystallites $>3 \mathrm{~nm}$ in size. Characterization by techniques such as DRUV-vis and X-ray absorption spectroscopy were next used to gain further insight into the Cu oxide structure.

\subsection{Cu catalysts characterized by DRUV-vis spectroscopy}

Diffuse reflectance UV-visible (DRUV-vis) spectroscopy gives valuable insight into metal oxide dispersion, coordination geometry, and oxidation state. First, a $d-d$ transition band is found between 600-900 nm for octahedrally coordinated $\mathrm{Cu}^{2+}$ or $1300-1600 \mathrm{~nm}$ for $\mathrm{Cu}^{2+}$ in a tetrahedral coordination

environment based on coordination geometry ${ }^{[40-42]}$, while bulk, crystalline $\mathrm{CuO}$ displays a single broad band centered around $650 \mathrm{~nm}^{[40]}$. The d orbitals of $\mathrm{Cu}^{+}$and $\mathrm{Cu}^{0}$ are filled, and therefore they do not 
display $d$-d transitions[36]. Figure 1 shows normalized DRUV-vis spectra of fresh Cu catalysts. All catalysts exhibit a peak in the $d$ - $d$ transition region (Fig. 1 inset) around $720-760 \mathrm{~nm}$, indicative of $\mathrm{Cu}^{2+}$ in an octahedral field[40]. The low $d$ - $d$ band absorption intensity of $0.14-\mathrm{L}_{2} \mathrm{Cu}_{6}$ compared with other catalysts indicates that it remained primarily as a $\mathrm{Cu}^{+}$species after synthesis, with only a minority $\mathrm{Cu}^{2+}$ species upon exposure to air.

Additionally, non-crystalline $\mathrm{Cu}^{2+}$ species exhibit an $\mathrm{O}_{2 \mathrm{p}} \rightarrow \mathrm{Cu}_{3 d}$ ligand to metal charge transfer (LMCT) band in the range $240-350 \mathrm{~nm}$. The wavelength of the LMCT peak maximum of metal oxides is often correlated with average metal oxide nuclearity. Isolated cations have the shortest wavelength LMCT which red shifts as metal oxide nuclearity increases and discrete energy levels hybridize into a band structure $[43,44]$. The $0.14 \mathrm{wt} \% \mathrm{Cu}^{2+}$ catalysts have similar DRUV-vis spectra well described by a two-Gaussian fit with a majority peak centered at $\lambda=238 \pm 3 \mathrm{~nm}(5.2 \mathrm{eV})$ and a minority species centered at $\lambda=266 \pm 2 \mathrm{~nm}(4.7 \mathrm{eV})$, while $1.4-\mathrm{Cu}\left(\mathrm{NO}_{3}\right)_{2}$ has one peak centered at $\lambda=266 \mathrm{~nm}$ with a tail at higher wavelengths. A LMCT band with $\lambda_{\max }<250 \mathrm{~nm}$ is assigned to an isolated $\mathrm{Cu}^{2+}$ cation in an octahedral field, while LMCT bands with $\lambda_{\max }>250 \mathrm{~nm}$ are assigned to sub-nanometer $\mathrm{Cu}^{2+}$ clusters and larger aggregates, based on comparison between the LMCT peak wavelength and fraction of EPR-active $\mathrm{Cu}$ in supported $\mathrm{Cu}$ catalysts by Tanaka et al[37]. Based on these assignments, fresh 0.14-Cu( $\left(\mathrm{NO}_{3}\right)_{2}, 0.14-$ $\left(\mathrm{NH}_{4}\right)_{2} \mathrm{CuEDTA}$, and $0.14-\mathrm{Na}_{2} \mathrm{CuEDTA}$ consist of primarily isolated $\mathrm{Cu}^{2+}$ cations and small $\mathrm{Cu}^{2+}$ clusters, while 1.4-Cu( $\left(\mathrm{NO}_{3}\right)_{2}$ consists of larger $\mathrm{Cu}^{2+}$ aggregates despite its low $\mathrm{Cu}$ surface density of $0.12 \mathrm{Cu} / \mathrm{nm}^{2}$.

The fresh $0.14-\mathrm{L}_{2} \mathrm{Cu}_{6}$ catalyst exists primarily as $\mathrm{Cu}^{+}$at room temperature shown vide infra, and therefore its DRUV-vis spectrum in figure 1 cannot be compared with $\mathrm{Cu}^{2+}$ catalysts. The peak at $260 \mathrm{~nm}$ in $0.14-L_{2} \mathrm{Cu}_{6}$ is assigned as a phenyl $\pi \rightarrow \pi^{*}$ transition in phenyl groups attached to the siloxide ligand. TGA-MS, figure S4, indicates that the siloxide ligand stays intact after $\mathrm{L}_{2} \mathrm{Cu}_{6}$ deposition. $A$ sharp peak at $220 \mathrm{~nm}$ and a broad band around $320 \mathrm{~nm}$ are both assigned to the $\mathrm{O}_{2 \mathrm{p}} \rightarrow \mathrm{Cu}_{4 \mathrm{~s}}$ transition[36] and indicate the presence of at least two populations of $\mathrm{Cu}^{+}$species.

\subsection{X-ray absorption spectroscopy of Cu catalysts}

$\mathrm{X}$-ray absorption spectroscopy gives insight into the oxidation state and local coordination environment of supported Cu catalysts. Figure 2 presents XANES spectra of the $\mathrm{L}_{2} \mathrm{Cu}_{6}$ precursor, a supported $\mathrm{Cu}\left(\mathrm{NO}_{3}\right)_{2}$ catalyst, and a supported $\mathrm{L}_{2} \mathrm{Cu}_{6}$ catalyst before and after calcination at $823 \mathrm{~K}$. Relevant transitions and edge energies, defined as the first inflection point in the near edge region, are listed in Table 2. $\mathrm{Cu}^{+}$and $\mathrm{Cu}^{2+}$ references exhibit a $1 \mathrm{~s} \rightarrow 4 \mathrm{p}$ transition at $8997 \mathrm{eV}$, while ligand field effects split the $4 p$ orbitals in $\mathrm{Cu}^{+}$creating a second, lower energy transition at $8983 \mathrm{eV}$ whose normalized height depends on $\mathrm{Cu}-\mathrm{O}$ coordination number[45]. $\mathrm{Cu}^{+}$in the $\mathrm{L}_{2} \mathrm{Cu}_{6}$ precursor is bound to two oxygen atoms in a linear configuration[29] and consequently exhibits a large feature at $8983 \mathrm{eV}$. Decreased absorption height at $8983 \mathrm{eV}$ in the supported $\mathrm{L}_{2} \mathrm{Cu}_{6}$ catalyst is consistent with increased $\mathrm{Cu}$ $\mathrm{O}$ coordination as $\mathrm{L}_{2} \mathrm{Cu}_{6}$ interacts with the support. A weak dipole-forbidden $1 \mathrm{~s} \rightarrow 3 \mathrm{~d}$ feature at $8978 \mathrm{eV}$ and a shoulder at $8986 \mathrm{eV}$ attributed to the $1 \mathrm{~s} \rightarrow 4 \mathrm{p}$ with ligand to metal "shake down" transition[46, 47] are characteristic of $\mathrm{Cu}^{2+}\left(3 \mathrm{~d}^{9}\right)$ compounds. The lack of absorption at $8978 \mathrm{eV}$ in figure 2 inset in supported $\mathrm{L}_{2} \mathrm{Cu}_{6}$, along with the characteristic $\mathrm{Cu}^{+}$transition at $8983 \mathrm{eV}$ and low edge energy below $8982 \mathrm{eV}$ prove supported $\mathrm{L}_{2} \mathrm{Cu}_{6}$ exists primarily in the +1 oxidation state.

Upon calcination at $823 \mathrm{~K}$, the supported $\mathrm{L}_{2} \mathrm{Cu}_{6}$ largely oxidizes to $\mathrm{Cu}^{2+}$, seen by the absorption edge shift to $8985 \mathrm{eV}$, but some $\mathrm{Cu}^{+}$may still be present as indicated by the weak band at $8983 \mathrm{eV}$. The 
resulting spectrum is nearly identical to supported $\mathrm{Cu}\left(\mathrm{NO}_{3}\right)_{2}$ indicating the $\mathrm{L}_{2} \mathrm{Cu}_{6}$ catalyst oxidizes to form structures similar to those present in other low surface density supported $\mathrm{Cu}\left(\mathrm{NO}_{3}\right)_{2}$ catalysts.

Figure 3 presents the magnitude of the $\mathrm{k}^{2}$-weighted Fourier transformation of the $\chi(k)$ function for the $\mathrm{L}_{2} \mathrm{Cu}_{6}$ precursor, a supported $\mathrm{Cu}\left(\mathrm{NO}_{3}\right)_{2}$ catalyst, and a supported $\mathrm{L}_{2} \mathrm{Cu}_{6}$ catalyst before and after calcination at $823 \mathrm{~K}$. The first two coordination shells of supported catalysts were fit to determine $\mathrm{Cu}-\mathrm{O}$ and $\mathrm{Cu}-\mathrm{Cu}$ bond lengths and coordination numbers and results are presented in table 3 . Bond lengths and coordination numbers for the $\mathrm{L}_{2} \mathrm{Cu}_{6}$ precursor are known from X-ray crystallographic data[29] and are also presented in table 3 for comparison. Each material has a large peak centered at 1.41-1.47 $\AA$ in figure 3 attributed to $\mathrm{Cu}-\mathrm{O}$ backscattering whose magnitude is related to $\mathrm{Cu}-\mathrm{O}$ coordination number and whose position is related to $\mathrm{Cu}-\mathrm{O}$ bond length. The supported $\mathrm{L}_{2} \mathrm{Cu}_{6}$ catalyst has an increased $\mathrm{Cu}-\mathrm{O}$ coordination number of 3.4 and increased $\mathrm{Cu}-\mathrm{O}$ bond length of $1.918 \AA$ A compared to the crystallographic data for the $\mathrm{L}_{2} \mathrm{Cu}_{6}$ precursor. This is consistent with XANES data and provides further evidence for interaction between $\mathrm{L}_{2} \mathrm{Cu}_{6}$ clusters and oxygens in the support. The $\mathrm{Cu}-\mathrm{O}$ backscattering peak increases in magnitude upon calcination in air at $823 \mathrm{~K}$ as average $\mathrm{Cu}-\mathrm{O}$ coordination number increases to 4.2. The Cu-O coordination number and bond length of calcined $\mathrm{L}_{2} \mathrm{Cu}_{6}$ catalyst are comparable to the $\mathrm{Cu}\left(\mathrm{NO}_{3}\right)_{2}$ catalyst suggesting that synthesis using either precursor leads to a similar $\mathrm{Cu}-\mathrm{O}$ coordination environment after aggressive oxidation.

In addition to the $\mathrm{Cu}-\mathrm{O}$ backscattering peak around $1.45 \AA$, all materials exhibit Fourier peaks between 2-3 $\AA$ due to $\mathrm{Cu}$-Cu scattering contributions. The $\mathrm{L}_{2} \mathrm{Cu}_{6}$ precursor has two $\mathrm{Cu}$ - $\mathrm{Cu}$ interactions at an average bond distance of $2.66 \AA$ which manifests as a $\mathrm{Cu}-\mathrm{Cu}$ scattering peak at $2.12 \AA$ in figure 3 . Upon supporting the $\mathrm{L}_{2} \mathrm{Cu}_{6}$ precursor, this peak shifts to longer scattering distances and decreases in magnitude, consistent with a bond distance of $2.95 \pm 0.01 \AA$ and average $\mathrm{Cu}$-Cu coordination number of 1.1 indicating some restructuring of the $\mathrm{Cu}_{6}$ cluster on the support. After calcination, the supported $\mathrm{L}_{2} \mathrm{Cu}_{6} \mathrm{Cu}$-Cu scattering peak increases in magnitude and is nearly identical to supported $\mathrm{Cu}\left(\mathrm{NO}_{3}\right)_{2}$ with an average $\mathrm{Cu}-\mathrm{Cu}$ coordination number of 5.0. The supported $\mathrm{L}_{2} \mathrm{Cu}_{6}$ and $\mathrm{Cu}\left(\mathrm{NO}_{3}\right)_{2}$ catalysts used for EXAFS analysis have a Cu surface density of $0.017 \mathrm{Cu} / \mathrm{nm}^{2}$, or about $0.3 \%$ of a copper oxide monolayer, at which loading few $\mathrm{Cu}-\mathrm{Cu}$ interactions are expected and supported by the DRUV-vis spectra in figure 1. Therefore, we assign the structure of these materials as predominantly small clusters or dimers, as illustrated in Scheme 2.

\subsection{Catalyst Reducibility}

Diffuse reflectance spectra in figure 4 taken during temperature programmed reduction (TPR) up to $573 \mathrm{~K}$ in $5 \% \mathrm{H}_{2} /$ Ar gives structural as well as reducibility information about the species present in these copper oxide catalysts that are most relevant for $\mathrm{ODH}$ catalysis. Reduction events are distinguished by tracking the $\mathrm{Cu}^{2+} \mathrm{d}$ - $\mathrm{d}$ transition band between $600-800 \mathrm{~nm}$ [40] as well as metallic interband transitions between $200-800 \mathrm{~nm}$ [48]. All of the catalysts except 0.14- $\mathrm{Na}_{2} \mathrm{CuEDTA}$ show complete disappearance of $\mathrm{Cu}^{2+}$ evidenced by the complete disappearance of the $\mathrm{d}$ - $\mathrm{d}$ absorption band at $760 \mathrm{~nm}$, but only the $1.4-\mathrm{Cu}\left(\mathrm{NO}_{3}\right)_{2}$ catalyst exhibited some reduction to $\mathrm{Cu}$ metal by $573 \mathrm{~K}$ based on the absorption intensity at $500 \mathrm{~nm}$ in figure 4 insets. In addition, the low intensity $\mathrm{d}$ - $\mathrm{d}$ band in 0.14 $\mathrm{L}_{2} \mathrm{Cu}_{6}$ completely disappears by $573 \mathrm{~K}$ which confirms the presence of a minor $\mathrm{Cu}^{2+}$ fraction for this catalyst in addition to the majority $\mathrm{Cu}^{+}$species identified by XANES. In contrast, $0.14-\mathrm{Na}_{2} \mathrm{CuEDTA}$ exhibits incomplete reduction of $\mathrm{Cu}^{2+}$ at $573 \mathrm{~K}$ seen in the inset of figure $4 \mathrm{e}$. This low reducibility 
compared to other catalysts is attributed to the $\mathrm{Na}^{+}$ion and is consistent with other reports that alkali doping decreases metal oxide reducibility $[49,50]$. These results are consistent with $\mathrm{H}_{2}$-TPR profiles in figure $\mathrm{S} 5$. All but the $0.14-\mathrm{Na}_{2} \mathrm{CuEDTA}$ catalyst exhibit a peak centered between $480-500 \mathrm{~K}$, which corresponds to a reduction from $\mathrm{Cu}^{2+} \rightarrow \mathrm{Cu}^{+}$based on DRUV-vis results. The 0.14- $\mathrm{Na}_{2} \mathrm{CuEDTA}$ catalyst exhibits broad, weak reduction from 423-823 K consistent with incomplete disappearance of the $d-d$ absorption band by $573 \mathrm{~K}$.

The reduced catalysts differ in $\mathrm{Cu}^{+}$speciation based on their charge transfer bands in the main plots of figure 4. The single apparent LMCT of the starting $\mathrm{Cu}^{2+}$ catalyst splits into two distinct absorption bands at 230-240 nm and 295-300 nm in all 0.14 wt \% Cu catalysts concurrent with reduction to $\mathrm{Cu}^{+}$. The relative intensity of these two bands is different between catalysts, indicating the bands arise from transitions in two different $\mathrm{Cu}^{+}$structures, rather than two different transitions arising from the same $\mathrm{Cu}^{+}$species. The 1.4-Cu( $\left(\mathrm{NO}_{3}\right)_{2}$ catalyst exhibits a single, lower energy band at $312 \mathrm{~nm}$ by $573 \mathrm{~K}$ concurrent with the reduction of all $\mathrm{Cu}^{2+}$. The total absorption of each of these 3 bands is comparable to that in the symmetry allowed $\mathrm{Cu}^{2+} \mathrm{LMCT}$ band, which suggests that they also arise from a symmetry allowed transition. Based on the energy levels for a $3 \mathrm{~d}^{10}$ metal in a distorted octahedral field, we assign the $\mathrm{Cu}^{+}$bands at 240,300, and $312 \mathrm{~nm}$ to an $\mathrm{O}_{2 \mathrm{p}} \rightarrow \mathrm{Cu}_{4 \mathrm{~s}}$ transition in structures with increasing $\mathrm{Cu}^{+}$ nuclearity. This is consistent with room temperature DRUV-vis spectra of fresh and spent catalysts which indicate $0.14 \mathrm{wt} \%$ catalysts are composed of isolated cations and small $\mathrm{Cu}^{2+}$ clusters while 1.4$\mathrm{Cu}\left(\mathrm{NO}_{3}\right)_{2}$ is composed of higher nuclearity $\mathrm{Cu}^{2+}$ aggregates than those of the lower surface density materials. The molar absorptivity of each band is unknown, but we posit that the ratio of pseudoabsorbances at 240 and $300 \mathrm{~nm}$ at $573 \mathrm{~K}$ gives information about the fraction of cations or small clusters present in $0.14 \mathrm{wt} \%$ catalysts. The ratios of pseudo-absorbance at $240 \mathrm{~nm}$ to $300 \mathrm{~nm}$ follow the order $\mathrm{F}\left(\mathrm{R}_{240}\right) / \mathrm{F}\left(\mathrm{R}_{300}\right)=1.33\left(0.14-\mathrm{L}_{2} \mathrm{Cu}_{6}\right)>1.00\left(0.14-\mathrm{Cu}\left(\mathrm{NO}_{3}\right)_{2}>0.48\left(0.14-\left(\mathrm{NH}_{4}\right)_{2} \mathrm{CuEDTA}\right)\right.$, and therefore 0.14$\mathrm{L}_{2} \mathrm{Cu}_{6}$ is expected to have the greatest number of isolated cations, followed by $0.14-\mathrm{Cu}\left(\mathrm{NO}_{3}\right)_{2}$ and 0.14 $\left(\mathrm{NH}_{4}\right)_{2} \mathrm{CuEDTA}$ respectively.

\subsection{Catalytic properties of supported $\mathrm{Cu}$ oxide catalysts for $\mathrm{ODH}$ of cyclohexane}

Catalytic tests were performed to determine how differences in $\mathrm{Cu}^{2+}$ nuclearity affect cyclohexane $\mathrm{ODH}$ chemistry. Additionally, a $1.1 \mathrm{wt} \% \mathrm{~V}$ catalyst, denoted $1.1-\mathrm{VO}_{\mathrm{x}}$, was synthesized and tested to compare $\mathrm{Cu}^{2+}$ activity with a typical vanadia catalyst. $\mathrm{C}_{6}$ hydrocarbon yields account for $98 \pm 5 \%$ of the total carbon content expected by mass balance for all reactions, indicating little $\mathrm{CO}_{\mathrm{x}}$ production. The two major products were cyclohexene and benzene, and selectivity is defined as in equation 3 as benzene production rate divided by cyclohexene and benzene rate. All catalysts deactivated upon use with no steady state attained after $36 \mathrm{~h}$ (Fig. S6), and all given rates and selectivities are initial rates and initial selectivities extrapolated back to zero time before deactivation. Turnover frequency (TOF) is calculated by normalizing measured product production rates by total metal content determined by elemental analysis, and apparent activation energies are calculated with respect to the consumption of cyclohexane.

Initial TOF and selectivity to benzene as a function of temperature are shown in figure 5 with select initial TOFs and apparent activation energies for the disappearance of cyclohexane calculated from the slope of In(TOF) vs. $1 /$ T reported in table 4 . Copper catalysts exhibit promising initial TOFs comparable to the vanadia catalyst, though the authors acknowledge that other factors such as stability 
or maximum metal loading influence the industrial viability of any given catalyst for ODH. All copper oxide catalysts have apparent activation energies of $60-70 \mathrm{~kJ} / \mathrm{mol}$, consistent with the activation energies of other reducible oxide catalysts on silica[14]. Similar apparent activation energies indicate that the rate limiting step for cyclohexane $\mathrm{ODH}$ is the same over all active $\mathrm{Cu}^{2+}$ species, and therefore differences in TOF primarily arise due to a difference in the number of active $\mathrm{Cu}^{2+}$ species per total $\mathrm{Cu}$ in each catalyst. Alkane ODH is reported to scale with the number of reducible sites[14]. Consistent with this, the $0.14-\mathrm{Na}_{2} \mathrm{CuEDTA}$ catalyst which contains a large fraction of unreducible $\mathrm{Cu}^{2+}$ (figure $4 \mathrm{e}$ inset) is least active for cyclohexane $\mathrm{ODH}$. The activity of all other copper oxide catalysts scales with the fraction of isolated cations and small clusters as determined from the absorption intensity of $\mathrm{Cu}^{+}$bands at 240 , 300 , and $312 \mathrm{~nm}$ in figure 4. This fraction is quantified by the ratio of pseudo-absorbance at $240 \mathrm{~nm}$ to $300 \mathrm{~nm}, \mathrm{~F}\left(\mathrm{R}_{240}\right) / \mathrm{F}\left(\mathrm{R}_{300}\right)$, for catalysts reduced at $573 \mathrm{~K}$ and presented in table 4 . The TOF of reducible copper oxide catalysts is proportional to $F\left(R_{240}\right) / F\left(R_{300}\right)$ at both temperatures tested, which indicates that cyclohexane $\mathrm{ODH}$ activity scales inversely with copper oxide nuclearity.

Selectivity to benzene in figure $5 \mathrm{~b}$ is insensitive to temperature at constant space velocity. Conversions vary by an order of magnitude over the temperature range tested, and it is not readily apparent from figure $5 b$ whether the apparent constant selectivity with temperature is an intrinsic property or due to compensating effects of temperature and conversion. With the exception of the largely redox inactive $0.14-\mathrm{Na}_{2} \mathrm{CuEDTA}$ catalyst, all the $\mathrm{Cu}$ oxide catalysts have a similar, high selectivity to benzene compared with 1.1- $\mathrm{VO}_{\mathrm{x}}$, despite having slightly different fractions of isolated cations and low nuclearity $\mathrm{Cu}^{2+}$ clusters. The reaction network is examined next to understand the origin of these apparent selectivity differences.

Alkane $\mathrm{ODH}$ proceeds by rate limiting $\mathrm{C}-\mathrm{H}$ bond abstraction followed by one or more additional $\mathrm{C}-\mathrm{H}$ abstractions to form cyclohexene or benzene directly[14]. Cyclohexene can also readsorb on a second active site and form benzene in a sequential reaction. This reaction network is depicted in scheme 3. Assuming pseudo-first order kinetics in cyclohexane, the reactant and product rates are given by:

$$
\begin{array}{ll}
\frac{d\left[C_{6} H_{12}\right]}{d t}=-\left(k_{1}+k_{2}\right)\left[C_{6} H_{12}\right] & \text { Eq. } 4 \\
\frac{d\left[C_{6} H_{10}\right]}{d t}=k_{1}\left[C_{6} H_{12}\right]-k_{3}\left[C_{6} H_{10}\right] & \text { Eq. } 5 \\
\frac{d\left[C_{6} H_{6}\right]}{d t}=k_{2}\left[C_{6} H_{12}\right]+k_{3}\left[C_{6} H_{10}\right] & \text { Eq. } 6
\end{array}
$$

Substituting benzene and cyclohexene rates in equations 5 and 6 into the definition of selectivity in equation 3 gives the selectivity to benzene as a function of cyclohexene concentration:

$$
S_{\text {Benzene }}=\frac{k_{2}}{k_{1}+k_{2}}+\frac{k_{3}}{k_{1}+k_{2}} \frac{\left[C_{6} H_{10}\right]}{\left[C_{6} H_{12}\right]}
$$

Selectivity to benzene therefore critically depends on the kinetics of competing pathways in scheme 3 . Direct pathway selectivity, $k_{2} / k_{1}$, can be calculated from $k_{2} /\left(k_{1}+k_{2}\right)$ using equations S3 and S4 while selectivity due to sequential oxidation reactions depends on $k_{3}$ and product yield through the concentration of cyclohexene.

Catalysts were tested at constant temperature and cyclohexane concentration while varying space velocity to measure selectivity changes with product yield. As seen in figure 6 , all catalysts exhibit a non-zero intercept and increasing selectivity with product yield, indicating that direct and sequential pathways both influence benzene selectivity. The 1.4- $\mathrm{Cu}\left(\mathrm{NO}_{3}\right)_{2}, 0.14-\mathrm{Cu}\left(\mathrm{NO}_{3}\right)_{2}$, and 0.14- $\left(\mathrm{NH}_{4}\right)_{2} \mathrm{CuEDTA}$ 
catalyst selectivities fall along the same curve, indicating they have the same intrinsic selectivity, and any apparent differences between them in figure $5 b$ are due to differences in conversion at the same space velocity. Direct pathway selectivity, $k_{2} / k_{1}$, is calculated from figure $\mathrm{S} 7$ and presented in table 4 . With the exception of $0.14-\mathrm{L}_{2} \mathrm{Cu}_{6}$, all other copper and vanadia catalysts have the same direct benzene selectivity of $5-10 \%$ within experimental error. The low direct benzene selectivity is in agreement with Feng et al. who found that direct benzene selectivity decreases with decreasing metal surface density for alumina supported vanadia catalysts[4]. The $0.14-\mathrm{L}_{2} \mathrm{Cu}_{6}$ catalyst exhibits a higher direct benzene selectivity of about $24 \%$ in addition to lower sequential benzene production and by extension lower $k_{3}$ than other $\mathrm{Na}$ free copper catalysts. This increased $k_{2} / k_{1}$ and decreased $k_{3}$ may be due to an electronic effect of nearby phenyl groups left over from the siloxide ligand, since these groups are found to be stable at reaction temperatures by TGA-MS as seen in figure S4. The 0.14- $\mathrm{Na}_{2} \mathrm{CuEDTA}$ catalyst exhibits a lower TOF and lower sequential oxidation capacity than other copper catalysts indicating $k_{1}, k_{2}$, and $k_{3}$ are all lowered on addition of $\mathrm{Na}$. This is consistent with the less redox active catalyst being less able to activate the $\mathrm{C}-\mathrm{H}$ bond for $\mathrm{ODH}$. The 1.1-VO $\mathrm{V}_{\mathrm{x}}$ catalyst exhibits a TOF similar to non-doped copper catalysts, but it differs from copper by having much lower sequential oxidation capacity as seen by the low slope in figure 6 . This may be due to lower readsorption of cyclohexene onto vanadia sites than on copper catalysts.

As mentioned above, these copper catalysts deactivate continuously over $36 \mathrm{~h}$, as can be seen in figure $\mathrm{S} 6$, where cyclohexene and benzene TOF both decline. The vanadia catalyst is much more stable than either $0.14-\mathrm{L}_{2} \mathrm{Cu}_{6}$ or $1.4-\mathrm{Cu}\left(\mathrm{NO}_{3}\right)_{2}$, losing only about $10 \%$ activity over $36 \mathrm{~h}$ compared with the loss of over $50 \%$ activity for either copper catalyst. Benzene TOF decreases much more quickly than cyclohexene TOF with time on stream for $0.14-\mathrm{L}_{2} \mathrm{Cu}_{6}$ and 1.4- $\mathrm{Cu}\left(\mathrm{NO}_{3}\right)_{2}$. However, the decrease in benzene TOF with decreasing yield is consistent with the selectivity vs. product yield curve for $0.14-\mathrm{L}_{2} \mathrm{Cu}_{6}$ and 1.4- $\mathrm{Cu}\left(\mathrm{NO}_{3}\right)_{2}$ in figure 6 . This indicates the intrinsic selectivity of the catalysts does not change during deactivation, and the effect of agglomeration is to change the number of active $\mathrm{Cu}^{2+}$ species per total $\mathrm{Cu}$ rather than to a change the mechanism or kinetics of $\mathrm{ODH}$. The origin of this change can be assigned to either coking or a structural rearrangement. Figure $\mathrm{S} 8$ shows TGA-MS profiles of $\mathrm{m} / \mathrm{z}=44$ (carbon dioxide) during calcination of spent catalysts. Integrating the mass loss associated with $\mathrm{CO}_{2}$ gives an upper bound of 0.05 wt \% carbon on the catalyst surface after reaction, which suggests coking is not a significant source of deactivation. Alternately, the change in activity can be associated with a change in the distribution of isolated, clustered, and aggregated $\mathrm{Cu}^{2+}$ under $\mathrm{ODH}$ reaction conditions as high energy structures agglomerate into lower energy ones. Normalized DRUV-vis spectra of spent catalysts in figure $\mathrm{S} 9$ show the LMCT transfer bands generally redshift 0.3-0.6 eV after being subjected to $\mathrm{ODH}$ conditions. The spectra also exhibit a low energy tail, suggesting the presence of a minority distribution of $\mathrm{Cu}^{2+}$ structures larger in extent than the majority species determined by the charge transfer peak wavelength. The peak wavelength redshift and long tail indicate that $\mathrm{Cu}$ structures initially present in fresh catalysts are not thermally stable and tend to agglomerate during reaction. The exception is again the 0.14- $\mathrm{Na}_{2} \mathrm{CuEDTA}$, which is stable, but less active. In spite of the shift in the DRUVvis, there are no diffraction lines present in powder XRD of 1.4-Cu( $\left(\mathrm{NO}_{3}\right)_{2}$ after cyclohexane $\mathrm{ODH}$ in figure $\mathrm{S} 10$. This indicates that $\mathrm{Cu}^{2+}$ crystallites are $<3.0 \mathrm{~nm}$ even after reaction, and crystallites present in 0.14 wt \% Cu catalysts are likely even smaller. 


\section{Conclusions}

Here we demonstrate the first report of nanostructured copper oxide activity towards ODH of alkanes. DRUV-vis and X-ray absorption spectroscopy of fresh catalysts show structural differences between catalysts with different loadings and precursors despite metal surface densities $<0.2 \mathrm{Cu} / \mathrm{nm}^{2}$. At least three copper species are identified by DRUV-vis based on $\mathrm{Cu}^{2+} \mathrm{LMCT}$ bands at 238, 266, and $>300 \mathrm{~nm}$ as well as $\mathrm{Cu}^{+} \mathrm{LMCT}$ bands at 235, 296, and $312 \mathrm{~nm}$ after reduction. The fraction of each copper species can be tuned by synthesis method, and use of the multinuclear $\mathrm{L}_{2} \mathrm{Cu}_{6}$ precursor led to the highest fraction of low nuclearity copper species. This is likely due to $\mathrm{L}_{2} \mathrm{Cu}_{6}$ depositing as small copper oxide domains with steric bulk from the siloxide ligand enforcing a minimum distance between deposited clusters.

Nuclearity trends combined with cyclohexane ODH studies show that activity scales inversely with copper oxide nuclearity. Selectivity to benzene is a function of the relative kinetics of direct and sequential pathways in scheme 3 as well as product yield, and it appears to be influenced by transition metal identity, alkali dopants, and the local ligand environment. All supported copper oxide catalysts exhibit high selectivity to selective oxidation products with negligible $\mathrm{CO}_{\mathrm{x}}$, in contrast to bulk, crystalline $\mathrm{CuO}$ which exhibited over $90 \%$ selectivity to $\mathrm{CO}_{\mathrm{x}}$ in the $\mathrm{ODH}$ of propane without additives such as tetrachloromethane[28]. Copper oxide catalysts exhibit comparable activity and higher subsequent $\mathrm{C}-$ $\mathrm{H}$ bond abstraction at the same conversion as a typical vanadia catalyst, apparently due to much faster sequential oxidation reactions, but their tendency to agglomerate during reaction will need to be overcome for industrial application. Potential methods for improving stability are to use a different support for which $\mathrm{Cu}^{2+}$ has a higher affinity or using a physical overcoat of secondary metal oxide, such as has been shown to improve stability of metallic $\mathrm{Cu}$ nanoparticles during liquid phase hydrogenation reactions[51,52]. Additional studies on the kinetics of these and related catalysts are currently under way.

\section{Acknowledgements}

This material is based upon work supported by the National Science Foundation Graduate Research Fellowship under Grant No. DGE-1324585 and by the Cluster of Excellence "Unifying Concepts in Catalysis" (EXC 314). This material is based upon work supported by the U.S. Department of Energy, Office of Science, Office of Basic Energy Sciences under Award Number DOE DE-FG02-03-ER154757. Portions of this work were performed with the valuable assistance of Dr. Qing Ma at the DuPontNorthwestern-Dow Collaborative Access Team (DND-CAT) located at Sector 5 of the Advanced Photon Source (APS). DND-CAT is supported by Northwestern University, E.I. DuPont de Nemours \& Co., and The Dow Chemical Company. This research used resources of the Advanced Photon Source, a U.S. Department of Energy (DOE) Office of Science User Facility operated for the DOE Office of Science by Argonne National Laboratory under Contract No. DE-AC02-06CH11357. S.L.N. would also like to thank Nick Thornburg for his assistance in collecting $x$-ray absorption data. The CleanCat Core facility acknowledges funding from the Department of Energy (DE-FG02-03ER15457) used for the purchase of the Altamira AMI-200. This work made use of the J.B. Cohen X-Ray Diffraction Facility supported by the 
MRSEC program of the National Science Foundation (DMR-1121262) at the Materials Research Center of Northwestern University. Metal analysis was performed at the Northwestern University Quantitative Bio-element Imaging Center.

\section{References}

[1] A. Dinse, B. Frank, C. Hess, D. Habel, R. Schomäcker, Oxidative dehydrogenation of propane over low-loaded vanadia catalysts: Impact of the support material on kinetics and selectivity, J. Mol. Catal. A-Chem., 289 (2008) 28-37.

[2] A. Dinse, S. Khennache, B. Frank, C. Hess, R. Herbert, S. Wrabetz, R. Schlögl, R. Schomäcker, Oxidative dehydrogenation of propane on silica (SBA-15) supported vanadia catalysts: A kinetic investigation, J. Mol. Catal. A-Chem., 307 (2009) 43-50.

[3] M.A. Smith, A. Zoelle, Y. Yang, R.M. Rioux, N.G. Hamilton, K. Amakawa, P.K. Nielsen, A. Trunschke, Surface roughness effects in the catalytic behavior of vanadia supported on SBA-15, Journal of Catalysis, 312 (2014) 170-178.

[4] H. Feng, J.W. Elam, J.A. Libera, M.J. Pellin, P.C. Stair, Oxidative dehydrogenation of cyclohexane over alumina-supported vanadium oxide nanoliths, Journal of Catalysis, 269 (2010) 421-431.

[5] K. Chen, A.T. Bell, E. Iglesia, Kinetics and Mechanism of Oxidative Dehydrogenation of Propane on Vanadium, Molybdenum, and Tungsten Oxides, The Journal of Physical Chemistry B, 104 (2000) 1292-1299.

[6] K.D. Chen, A. Khodakov, J. Yang, A.T. Bell, E. Iglesia, Isotopic tracer and kinetic studies of oxidative dehydrogenation pathways on vanadium oxide catalysts, Journal of Catalysis, 186 (1999) 325-333.

[7] E.C. Tyo, C.R. Yin, M. Di Vece, Q. Qian, G. Kwon, S. Lee, B. Lee, J.E. DeBartolo, S. Seifert, R.E. Winans, R. Si, B. Ricks, S. Goergen, M. Rutter, B. Zugic, M. Flytzani-Stephanopoulos, Z.W. Wang, R.E. Palmer, M. Neurock, S. Vajda, Oxidative Dehydrogenation of Cyclohexane on Cobalt Oxide (Co304) Nanoparticles: The Effect of Particle Size on Activity and Selectivity, ACS Catal., 2 (2012) 24092423.

[8] E.C. Alyea, M.A. Keane, The oxidative dehydrogenation of cyclohexane and cyclohexene over unsupported and supported molybdena catalysts prepared by metal oxide vapor deposition, Journal of Catalysis, 164 (1996) 28-35.

[9] M.C. Kung, H.H. Kung, Oxidative dehydrogenation of cyclohexane over vanadate catalysts, Journal of Catalysis, 128 (1991) 287-291.

[10] M. Jin, P. Lu, G.X. Yu, Z.M. Cheng, L.F. Chen, J.A. Wang, Effect of additives doping on catalytic properties of Mg-3(VO4)(2) catalysts in oxidative dehydrogenation of cyclohexane, Catal. Today, 212 (2013) 142-148.

[11] M. Jin, Z.M. Cheng, Oxidative Dehydrogenation of Cyclohexane to Cyclohexene over Mg-V-O Catalysts, Catalysis Letters, 131 (2009) 266-278.

[12] S. Sugiyama, T. Hashimoto, Y. Tanabe, N. Shigemoto, H. Hayashi, Effects of the enhancement of the abstraction of lattice oxygen from magnesium vanadates incorporated with copper(II) cations on the oxidative dehydrogenation of propane, J. Mol. Catal. A-Chem., 227 (2005) 255-261.

[13] R. Grabowski, Kinetics of oxidative dehydrogenation of C(2)-C(3) alkanes on oxide catalysts, Catal. Rev.-Sci. Eng., 48 (2006) 199-268.

[14] C.A. Carrero, R. Schlögl, I.E. Wachs, R. Schomäcker, Critical Literature Review of the Kinetics for the Oxidative Dehydrogenation of Propane over Well-Defined Supported Vanadium Oxide Catalysts, ACS Catal., 4 (2014) 3357-3380.

[15] Y.M. Liu, Y. Cao, S.R. Yan, W.L. Dai, K.N. Fan, Highly effective oxidative dehydrogenation of propane over vanadia supported on mesoporous SBA-15 silica, Catalysis Letters, 88 (2003) 61-67. 
[16] B. Schimmoeller, Y.J. Jiang, S.E. Pratsinis, A. Baiker, Structure of flame-made vanadia/silica and catalytic behavior in the oxidative dehydrogenation of propane, Journal of Catalysis, 274 (2010) 6475.

[17] M.D. Argyle, K.D. Chen, A.T. Bell, E. Iglesia, Effect of catalyst structure on oxidative dehydrogenation of ethane and propane on alumina-supported vanadia, Journal of Catalysis, 208 (2002) 139-149.

[18] P. Gruene, T. Wolfram, K. Pelzer, R. Schlögl, A. Trunschke, Role of dispersion of vanadia on SBA15 in the oxidative dehydrogenation of propane, Catal. Today, 157 (2010) 137-142.

[19] H.J. Tian, E.I. Ross, I.E. Wachs, Quantitative determination of the speciation of surface vanadium oxides and their catalytic activity, J. Phys. Chem. B, 110 (2006) 9593-9600.

[20] P. Vanelderen, J. Vancauwenbergh, M.L. Tsai, R.G. Hadt, E.I. Solomon, R.A. Schoonheydt, B.F. Sels, Spectroscopy and Redox Chemistry of Copper in Mordenite, ChemPhysChem, 15 (2014) 91-99. [21] E. Roduner, W. Kaim, B. Sarkar, V.B. Urlacher, J. Pleiss, R. Glaser, W.D. Einicke, G.A. Sprenger, U. Beifuss, E. Klemm, C. Liebner, H. Hieronymus, S.F. Hsu, B. Plietker, S. Laschat, Selective Catalytic Oxidation of C-H Bonds with Molecular Oxygen, ChemCatChem, 5 (2013) 82-112.

[22] E.I. Solomon, J.W. Ginsbach, D.E. Heppner, M.T. Kieber-Emmons, C.H. Kjaergaard, P.J. Smeets, L. Tian, J.S. Woertink, Copper dioxygen (bio)inorganic chemistry, Faraday Discussions, 148 (2011) 1139.

[23] J.L. Gu, Y. Huang, S.P. Elangovan, Y.S. Li, W.R. Zhao, I. Toshio, Y. Yamazaki, J.L. Shi, Highly Dispersed Copper Species within SBA-15 Introduced by the Hydrophobic Core of a Surfactant Micelle as a Carrier and Their Enhanced Catalytic Activity for Cyclohexane Oxidation, J. Phys. Chem. C, 115 (2011) 21211-21217.

[24] B. Sarkar, P. Prajapati, R. Tiwari, R. Tiwari, S. Ghosh, S.S. Acharyya, C. Pendem, R.K. Singha, L.N.S. Konathala, J. Kumar, T. Sasaki, R. Bal, Room temperature selective oxidation of cyclohexane over Cu-nanoclusters supported on nanocrystalline Cr203, Green Chem., 14 (2012) 2600-2606. [25] A. Conde, L. Vilella, D. Balcells, M.M. Diaz-Requejo, A. Lledos, P.J. Perez, Introducing Copper as Catalyst for Oxidative Alkane Dehydrogenation, Journal of the American Chemical Society, 135 (2013) 3887-3896.

[26] X.G. Duan, W.M. Liu, L.M. Yue, W. Fu, M.N. Ha, J. Li, G.Z. Lu, Selective oxidation of cyclohexane on a novel catalyst Mg-Cu/SBA-15 by molecular oxygen, Dalton Trans., 44 (2015) 17381-17388.

[27] S. Sugiyama, T. Shono, E. Nitta, H. Hayashi, Effects of gas- and solid-phase additives on oxidative dehydrogenation of propane on strontium and barium hydroxyapatites, Appl. Catal. AGen., 211 (2001) 123-130.

[28] S. Sugiyama, N. Fukuda, H. Hayashi, Effect of tetrachloromethane on redox behaviors of copper(II) oxide in the oxidative dehydrogenation of propane, Catalysis Letters, 78 (2002) 139-143. [29] F. Schax, B. Braun, C. Limberg, A Tripodal Trisilanol Ligand and Its Complexation Behavior towards CuI, CuII, and ZnII, Eur. J. Inorg. Chem., 2014 (2014) 2124-2130.

[30] T.W. Kim, F. Kleitz, B. Paul, R. Ryoo, MCM-48-like large mesoporous silicas with tailored pore structure: Facile synthesis domain in a ternary triblock copolymer-butanol-water system, Journal of the American Chemical Society, 127 (2005) 7601-7610.

[31] D. Prieto-Centurion, Supported Oxide Catalysts from Chelating Precursors, in: Chemical and Biological Engineering, Northwestern University, 2013, pp. 159.

[32] G. Du, S. Lim, M. Pinault, C. Wang, F. Fang, L. Pfefferle, G.L. Haller, Synthesis, characterization, and catalytic performance of highly dispersed vanadium grafted SBA-15 catalyst, Journal of Catalysis, 253 (2008) 74-90.

[33] E.S. Vasiliadou, T.M. Eggenhuisen, P. Munnik, P.E. de Jongh, K.P. de Jong, A.A. Lemonidou, Synthesis and performance of highly dispersed $\mathrm{Cu} / \mathrm{SiO} 2$ catalysts for the hydrogenolysis of glycerol, Appl. Catal. B-Environ., 145 (2014) 108-119.

[34] I.K. Mbaraka, B.H. Shanks, Design of multifunctionalized mesoporous silicas for esterification of fatty acid, Journal of Catalysis, 229 (2005) 365-373. 
[35] B.R. Strohmeier, D.E. Leyden, R.S. Field, D.M. Hercules, Surface spectroscopic characterization of $\mathrm{Cu} / \mathrm{Al} 203$ catalysts, Journal of Catalysis, 94 (1985) 514-530.

[36] T. Yamamoto, T. Tanaka, R. Kuma, S. Suzuki, F. Amano, Y. Shimooka, Y. Kohno, T. Funabiki, S. Yoshida, NO reduction with $\mathrm{CO}$ in the presence of O-2 over Al203-supported and Cu-based catalysts, Phys. Chem. Chem. Phys., 4 (2002) 2449-2458.

[37] F. Amano, S. Suzuki, T. Yamamoto, T. Tanaka, One-electron reducibility of isolated copper oxide on alumina for selective NO-CO reaction, Appl. Catal. B-Environ., 64 (2006) 282-289.

[38] C.M. Chanquia, K. Sapag, E. Rodriguez-Castellon, E.R. Herrero, G.A. Eimer, Nature and Location of Copper Nanospecies in Mesoporous Molecular Sieves, J. Phys. Chem. C, 114 (2010) 1481-1490.

[39] N.F. Balsamo, C.M. Chanquia, E.R. Herrero, S.G. Casuscelli, M.E. Crivello, G.A. Eimer,

Dehydrogenation of Isopropanol on Copper-Containing Mesoporous Catalysts, Industrial \& Engineering Chemistry Research, 49 (2010) 12365-12370.

[40] H. Praliaud, S. Mikhailenko, Z. Chajar, M. Primet, Surface and bulk properties of Cu-ZSM-5 and $\mathrm{Cu} / \mathrm{Al} 203$ solids during redox treatments. Correlation with the selective reduction of nitric oxide by hydrocarbons, Appl. Catal. B-Environ., 16 (1998) 359-374.

[41] R.M. Friedman, J.J. Freeman, F.W. Lytle, Characterization of Cu-Al203 catalysts, Journal of Catalysis, 55 (1978) 10-28.

[42] J.J. Bravo-Suarez, B. Subramaniam, R.V. Chaudhari, Ultraviolet-Visible Spectroscopy and Temperature-Programmed Techniques as Tools for Structural Characterization of $\mathrm{Cu}$ in $\mathrm{CuMgAlOx}$ Mixed Metal Oxides, J. Phys. Chem. C, 116 (2012) 18207-18221.

[43] D.G. Barton, M. Shtein, R.D. Wilson, S.L. Soled, E. Iglesia, Structure and Electronic Properties of Solid Acids Based on Tungsten Oxide Nanostructures, The Journal of Physical Chemistry B, 103 (1999) 630-640.

[44] X.T. Gao, I.E. Wachs, Investigation of surface structures of supported vanadium oxide catalysts by UV-vis-NIR diffuse reflectance spectroscopy, J. Phys. Chem. B, 104 (2000) 1261-1268.

[45] L.S. Kau, D.J. Spirasolomon, J.E. Pennerhahn, K.O. Hodgson, E.I. Solomon, X-ray absorption-edge determination of the oxidation-state and coordination-number of copper - application to the type-3 site in rhus-vernicifera laccase and its reaction with oxygen, Journal of the American Chemical Society, 109 (1987) 6433-6442.

[46] I.J. Drake, K.L. Fujdala, S. Baxamusa, A.T. Bell, T.D. Tilley, Effects of precursor composition on the local structure of $\mathrm{Cu}$ dispersed on mesoporous silica: A detailed X-ray absorption spectroscopy study, J. Phys. Chem. B, 108 (2004) 18421-18434.

[47] R.K. Hocking, E.I. Solomon, Ligand Field and Molecular Orbital Theories of Transition Metal Xray Absorption Edge Transitions, Struct. Bond., 142 (2012) 155-184.

[48] P.B. Johnson, R.W. Christy, Optical Constants of the Noble Metals, Phys. Rev. B, 6 (1972) 43704379.

[49] D. Prieto-Centurion, J.M. Notestein, Surface speciation and alkane oxidation with highly dispersed Fe(III) sites on silica, Journal of Catalysis, 279 (2011) 103-110.

[50] D. Prieto-Centurion, A.M. Boston, J.M. Notestein, Structural and electronic promotion with alkali cations of silica-supported Fe(III) sites for alkane oxidation, Journal of Catalysis, 296 (2012) 77-85.

[51] B.J. O'Neill, D.H.K. Jackson, A.J. Crisci, C.A. Farberow, F.Y. Shi, A.C. Alba-Rubio, J.L. Lu, P.J. Dietrich, X.K. Gu, C.L. Marshall, P.C. Stair, J.W. Elam, J.T. Miller, F.H. Ribeiro, P.M. Voyles, J. Greeley, M. Mavrikakis, S.L. Scott, T.F. Kuech, J.A. Dumesic, Stabilization of Copper Catalysts for Liquid-Phase Reactions by Atomic Layer Deposition, Angew. Chem.-Int. Edit., 52 (2013) 13808-13812. [52] B.J. O'Neill, J.T. Miller, P.J. Dietrich, F.G. Sollberger, F.H. Ribeiro, J.A. Dumesic, Operando X-ray Absorption Spectroscopy Studies of Sintering for Supported Copper Catalysts during Liquid-phase Reaction, ChemCatChem, 6 (2014) 2493-2496. 


\section{Table Titles and Scheme / Figure Captions.}

Table 1. Catalyst and KIT-6 support properties

Table 2. Cu K edge energies and relevant transitions

Table 3. Fitting results for supported copper oxide catalysts

Table 4. Apparent activation energies, TOFs, and direct pathway selectivity of copper and vanadium oxide catalysts.

Scheme 1. Structure of $\mathrm{L}_{2} \mathrm{Cu}_{6}$ (left) and core motif (right) showing Si (gray), $\mathrm{O}$ (red), and $\mathrm{Cu}$ (cyan) atoms with phenyl ligands omitted for clarity.

Scheme 2. Potential supported $\mathrm{Cu}^{2+}$ species, including monomer, dimer, and oligomeric species

Scheme 3. Cyclohexane ODH reaction network

Figure 1. DRUV-vis spectra of fresh Cu catalysts. $0.14-\mathrm{L}_{2} \mathrm{Cu}_{6}$ (red), 0.14-Cu( $\left(\mathrm{NO}_{3}\right)_{2}$ (cyan), 0.14- $\left(\mathrm{NH}_{4}\right)_{2} \mathrm{CuEDTA}$ (orange), 0.14- $\mathrm{Na}_{2} \mathrm{CuEDTA}$ (green), 1.4-Cu( $\left(\mathrm{NO}_{3}\right)_{2}$ (blue). Inset shows the lower-energy $\mathrm{d}$-d transition region.

Figure 2. $\mathrm{Cu} \mathrm{K}$ edge XANES spectra of $\mathrm{L}_{2} \mathrm{Cu}_{6}$ precursor (black), $0.2-\mathrm{L}_{2} \mathrm{Cu}_{6}$ catalyst (red), $0.2-\mathrm{L}_{2} \mathrm{Cu}_{6}$ catalyst calcined $823 \mathrm{~K}$ in air (red dashed), and 0.2- $\mathrm{Cu}\left(\mathrm{NO}_{3}\right)_{2}$ catalyst (cyan) with edge energy marked with an $\mathrm{X}$ for clarity. Vertical dashed lines mark transitions associated with $\mathrm{Cu}^{+}$and $\mathrm{Cu}^{2+}$ at 8983 and $8987 \mathrm{eV}$ respectively. Inset marks $1 \mathrm{~s} \rightarrow 3 \mathrm{~d}$ transition.

Figure 3. Magnitude of the Fourier transformed $\mathrm{k}^{2}$-weighted EXAFS function.

Figure 4. DRUV-vis spectra of catalysts under $3.7 \mu \mathrm{mol} / \mathrm{s}$ flow of $5 \% \mathrm{H}_{2} / \mathrm{He}$ between $333-573 \mathrm{~K}$. Main figures show $\mathrm{LMCT}$ region while insets show $\mathrm{d}$-d transition region. A) 0.14- $\left.\mathrm{L}_{2} \mathrm{Cu}_{6}, \mathrm{~B}\right)$ 1.4- $\left.\mathrm{Cu}\left(\mathrm{NO}_{3}\right)_{2}, \mathrm{C}\right)$ 0.14-Cu( $\left.\left.\mathrm{NO}_{3}\right)_{2}, \mathrm{D}\right)$ 0.14- $\left(\mathrm{NH}_{4}\right)_{2} \mathrm{CuEDTA}$, E) 0.14- $\mathrm{Na}_{2} \mathrm{CuEDTA}$

Figure 5. Temperature dependence of cyclohexane $\mathrm{ODH}$ (a) turnover frequency and (b) selectivity to benzene. Reaction conditions: $\mathrm{C}_{6} \mathrm{H}_{12}: \mathrm{O}_{2}: \mathrm{He}=1: 4.7: 94.3$, space velocity $=540$ mol C$_{6} \mathrm{H}_{12} /($ mol metal $*$ hr), $\mathrm{P}=1.01$ bar, $v_{\text {total }}=31.6 \mu \mathrm{mol} / \mathrm{s}$ gas.

Figure 6. Selectivity to benzene as a function of product yield. Reaction conditions: $T=573 \mathrm{~K}, \mathrm{C}_{6} \mathrm{H}_{12}: \mathrm{O}_{2}: \mathrm{He}=$ 1:4.7:94.3, space velocity $=230-1770 \mathrm{~mol} \mathrm{C}_{6} \mathrm{H}_{12} /(\mathrm{mol}$ metal $* \mathrm{hr}), \mathrm{P}=1.01 \mathrm{bar}, \mathrm{v}_{\text {total }}=16.6-64.0 \mu \mathrm{mol} / \mathrm{s}$ gas. 
Table 1. Catalyst and KIT-6 support properties

\begin{tabular}{|c|c|c|c|c|c|c|}
\hline \multirow[b]{2}{*}{ Catalyst } & \multicolumn{2}{|c|}{ Support properties } & \multicolumn{4}{|c|}{ Catalyst properties } \\
\hline & $\begin{array}{l}\text { Surface } \\
\text { area } \\
\left(\mathrm{m}^{2} / \mathrm{g}\right)\end{array}$ & $\begin{array}{l}\text { Pore } \\
\text { volume } \\
\left(\mathrm{cm}^{3} / \mathrm{g}\right)\end{array}$ & $\begin{array}{l}\text { M } \\
\text { loading } \\
\text { (wt \%) }\end{array}$ & $\begin{array}{l}\text { Surface } \\
\text { density } \\
\left(\mathrm{M} / \mathrm{nm}^{2}\right)\end{array}$ & $\begin{array}{l}\text { Surface } \\
\text { area } \\
\left(\mathrm{m}^{2} / \mathrm{g}\right)\end{array}$ & $\begin{array}{l}\text { Pore } \\
\text { volume } \\
\left(\mathrm{cm}^{3} / \mathrm{g}\right)\end{array}$ \\
\hline $0.14-\mathrm{L}_{2} \mathrm{Cu}_{6}$ & 900 & 0.84 & $0.12 \%$ & 0.012 & 1000 & 0.90 \\
\hline $1.4-\mathrm{Cu}\left(\mathrm{NO}_{3}\right)_{2}$ & 1100 & 1.0 & $1.30 \%$ & 0.12 & 890 & 0.89 \\
\hline $0.14-\mathrm{Cu}\left(\mathrm{NO}_{3}\right)_{2}$ & 900 & 0.84 & $0.14 \%$ & 0.014 & 960 & 0.89 \\
\hline $0.14-\left(\mathrm{NH}_{4}\right)_{2} \mathrm{CuEDTA}$ & 830 & 0.88 & $0.17 \%$ & 0.015 & 800 & 0.86 \\
\hline $0.14-\mathrm{Na}_{2} \mathrm{CuEDTA}$ & 830 & 0.88 & $0.14 \%$ & 0.014 & 600 & 0.75 \\
\hline $1.1-\mathrm{VO}_{\mathrm{x}}$ & 830 & 0.88 & $1.1 \%$ & 0.15 & & \\
\hline
\end{tabular}

Table 2. Cu K edge energies and relevant transitions

\begin{tabular}{lllll}
\hline Material & $\begin{array}{l}\mathrm{E}_{\mathbf{0}} \\
(\mathrm{eV})\end{array}$ & $\begin{array}{l}\text { 1s } \rightarrow \text { 4p } \\
(\mathrm{eV})\end{array}$ & $\begin{array}{l}\text { 1s } \rightarrow \text { 4p } \\
(\mathrm{eV})\end{array}$ & $\begin{array}{l}\text { 1s } \rightarrow \text { 3d } \\
(\mathrm{eV})\end{array}$ \\
\hline $\mathrm{L}_{2} \mathrm{Cu}_{6}$ precursor & 8981.9 & 8994.3 & 8982.3 & \\
$0.2-\mathrm{L}_{2} \mathrm{Cu}_{6}$ & 8981.5 & 8997.3 & 8982.8 & \\
$0.2-\mathrm{L}_{2} \mathrm{Cu}_{6}, \Delta 823 \mathrm{~K}$ & 8985.3 & 8997.8 & 8982.8 & 8977.5 \\
$0.2-\mathrm{Cu}\left(\mathrm{NO}_{3}\right)_{2}$ & 8985.4 & 8997.8 & 8982.8 & 8977.5
\end{tabular}

Table 3. Fitting results for supported copper oxide catalysts

\begin{tabular}{|c|c|c|c|c|c|c|}
\hline Material & Shell & $\mathrm{CN}^{\mathrm{a}}$ & $R(\AA)^{b}$ & $\sigma^{2}\left(\AA^{2}\right)^{c}$ & $\Delta \mathrm{E}_{0}(\mathrm{eV})^{\mathrm{d}}$ & R-factor ${ }^{e}$ \\
\hline \multirow[t]{2}{*}{$\mathrm{L}_{2} \mathrm{Cu}_{6}$ precursor $^{f}$} & $\mathrm{Cu}-\mathrm{O}$ & 2 & $1.839^{g}$ & & & \\
\hline & $\mathrm{Cu}-\mathrm{Cu}$ & 2 & $2.66^{\mathrm{h}}$ & & & \\
\hline \multirow[t]{2}{*}{$0.2-\mathrm{L}_{2} \mathrm{Cu}_{6}$} & $\mathrm{Cu}-\mathrm{O}$ & 3.4 & 1.918 & 0.0072 & 8.32 & 0.0013 \\
\hline & $\mathrm{Cu}-\mathrm{Cu}$ & 1.1 & 2.941 & 0.0074 & 8.41 & 0.0013 \\
\hline \multirow[t]{2}{*}{$0.2-\mathrm{L}_{2} \mathrm{Cu}_{6} \Delta 823 \mathrm{~K}$} & $\mathrm{Cu}-\mathrm{O}$ & 4.2 & 1.925 & 0.0060 & 4.05 & 0.0023 \\
\hline & $\mathrm{Cu}-\mathrm{Cu}$ & 5.0 & 2.962 & 0.0164 & 8.28 & 0.0031 \\
\hline \multirow[t]{2}{*}{$0.2-\mathrm{Cu}\left(\mathrm{NO}_{3}\right)_{2}$} & $\mathrm{Cu}-\mathrm{O}$ & 4.1 & 1.913 & 0.0051 & 2.84 & 0.0003 \\
\hline & $\mathrm{Cu}-\mathrm{Cu}$ & 5.3 & 2.952 & 0.0110 & 7.82 & 0.0018 \\
\hline
\end{tabular}

${ }^{a}$ Coordination number. ${ }^{b}$ Fitted radial distance. ${ }^{c}$ Debye-Waller factor. ${ }^{d}$ Energy reference shift. ${ }^{\mathrm{e}} \mathrm{R}$-factor defined in eq S2. ${ }^{f}$ Coordination numbers and bond lengths taken from crystallographic data. ${ }^{\mathrm{g}}$ Average of $1^{\text {st }} \mathrm{Cu}-\mathrm{O}$ shell distances. ${ }^{\mathrm{h}}$ Average of $1^{\text {st }} \mathrm{Cu}$-Cu shell distances. 
Table 4. Apparent activation energies, TOFs, and direct pathway selectivity of copper and vanadium oxide catalysts.

\begin{tabular}{|c|c|c|c|c|c|}
\hline \multirow[b]{2}{*}{ Catalyst } & \multirow{2}{*}{$\begin{array}{l}F\left(R_{240}\right) / \\
F\left(R_{300}\right)^{a}\end{array}$} & \multirow{2}{*}{$\begin{array}{c}E_{A} \\
(\mathrm{~kJ} / \mathrm{mol})\end{array}$} & \multicolumn{2}{|c|}{$10^{4} *$ TOF $\left(s^{-1}\right)$} & \multirow[b]{2}{*}{$k_{2} / k_{1}$} \\
\hline & & & $523 \mathrm{~K}$ & $623 \mathrm{~K}$ & \\
\hline $0.14-\mathrm{L}_{2} \mathrm{Cu}_{6}$ & 1.33 & 64. & 2.3 & 32.4 & 0.24 \\
\hline $0.14-\mathrm{Cu}\left(\mathrm{NO}_{3}\right)_{2}$ & 1.00 & 64. & 2.2 & 19.6 & 0.04 \\
\hline $0.14-\left(\mathrm{NH}_{4}\right)_{2} \mathrm{CuEDTA}$ & 0.48 & 70. & 1.7 & 14.9 & 0.11 \\
\hline $1.4-\mathrm{Cu}\left(\mathrm{NO}_{3}\right)_{2}$ & 0.14 & 61. & 1.1 & 9.8 & 0.10 \\
\hline $1.1-\mathrm{VO}_{\mathrm{x}}$ & --- & 83. & 0.6 & 13.5 & 0.08 \\
\hline $0.14-\mathrm{Na}_{2} \mathrm{CuEDTA}$ & $0.77^{b}$ & 69. & 0.5 & 5.7 & 0.03 \\
\hline
\end{tabular}

${ }^{a}$ ratio of pseudo-absorbance at $240 \mathrm{~nm}$ to $300 \mathrm{~nm}$ for catalysts reduced at $573 \mathrm{~K}$ under $3.7 \mu \mathrm{mol} / \mathrm{s}$ flow of $5 \% \mathrm{H}_{2} /$ He. ${ }^{b}$ Ratio of selectivity to benzene vs. cyclohexene from direct reaction of cyclohexane. ${ }^{c}$ LMCT from large fraction of unreducible $\mathrm{Cu}^{2+}$ included in ratio. 


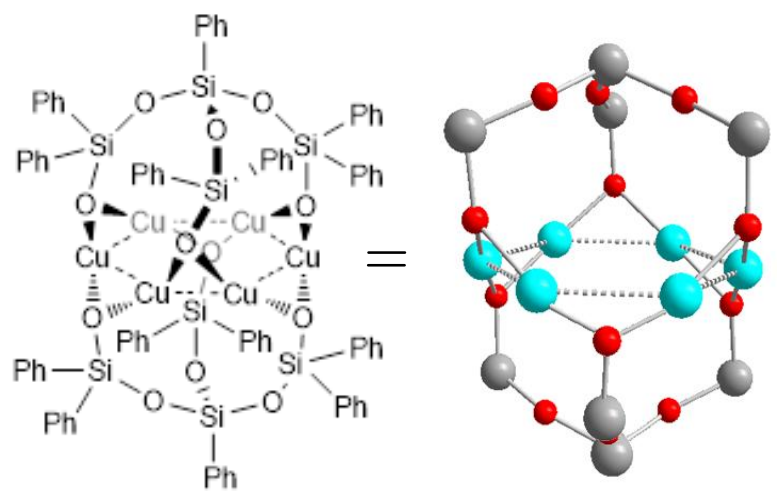

Scheme 1. Structure of $\mathrm{L}_{2} \mathrm{Cu}_{6}$ (left) and core motif (right) showing $\mathrm{Si}$ (gray), $\mathrm{O}$ (red), and $\mathrm{Cu}$ (cyan) atoms with phenyl ligands omitted for clarity.
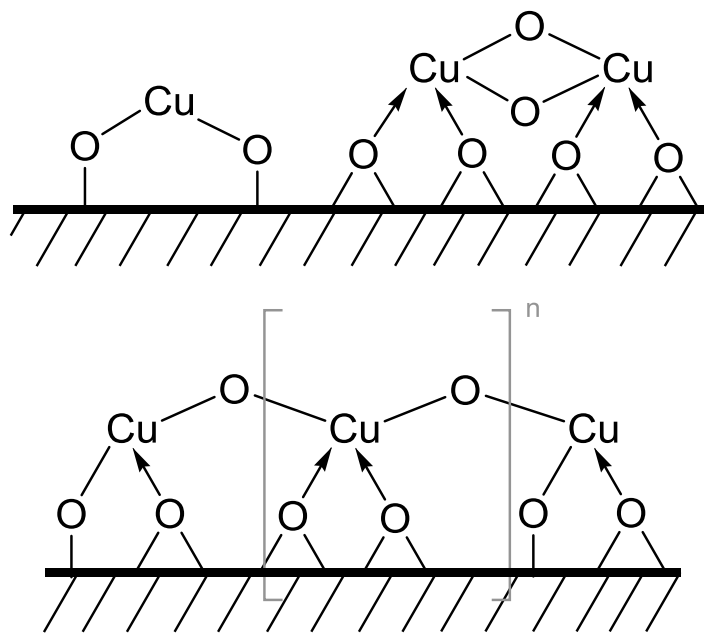

Scheme 2. Potential supported $\mathrm{Cu}^{2+}$ species, including monomer, dimer, and oligomeric species

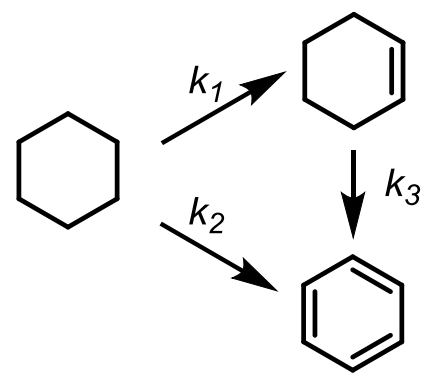

Scheme 3. Cyclohexane ODH reaction network. 


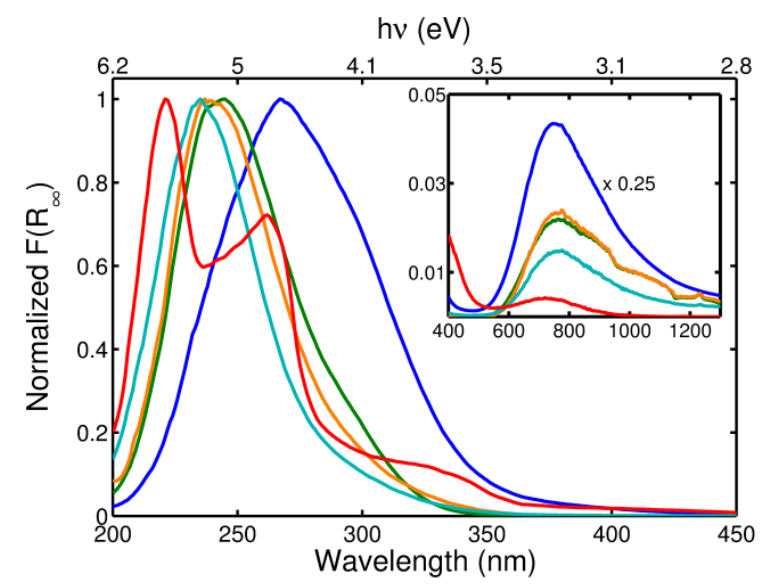

Figure 1. DRUV-vis spectra of fresh Cu catalysts. $0.14-\mathrm{L}_{2} \mathrm{Cu}_{6}$ (red), 0.14-Cu( $\left(\mathrm{NO}_{3}\right)_{2}$ (cyan), 0.14- $\left(\mathrm{NH}_{4}\right)_{2} \mathrm{CuEDTA}$ (orange), 0.14- $\mathrm{Na}_{2} \mathrm{CuEDTA}$ (green), 1.4-Cu( $\left.\mathrm{NO}_{3}\right)_{2}$ (blue). Inset shows the lower-energy d-d transition region.

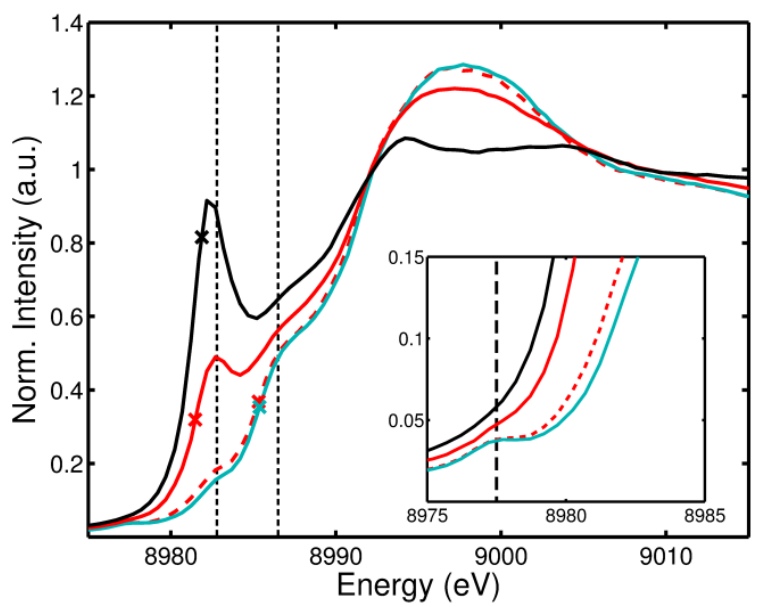

Figure 2. $\mathrm{Cu} \mathrm{K}$ edge XANES spectra of $\mathrm{L}_{2} \mathrm{Cu}_{6}$ precursor (black), $0.2-\mathrm{L}_{2} \mathrm{Cu}_{6}$ catalyst (red), $0.2-\mathrm{L}_{2} \mathrm{Cu}_{6}$ catalyst calcined $823 \mathrm{~K}$ in air (red dashed), and 0.2- $\mathrm{Cu}\left(\mathrm{NO}_{3}\right)_{2}$ catalyst (cyan) with edge energy marked with an $\mathrm{X}$ for clarity. Vertical dashed lines mark transitions associated with $\mathrm{Cu}^{+}$and $\mathrm{Cu}^{2+}$ at 8983 and $8987 \mathrm{eV}$ respectively. Inset marks $1 \mathrm{~s} \rightarrow 3 \mathrm{~d}$ transition.

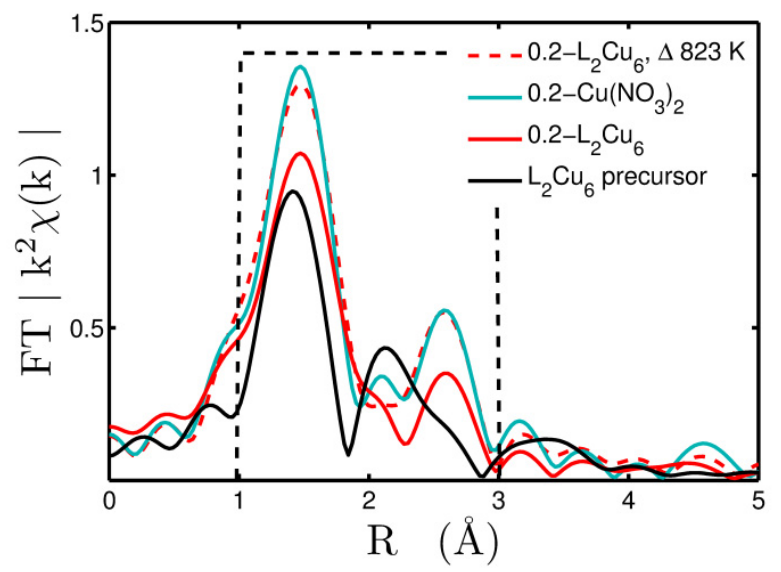

Figure 3. Magnitude of the Fourier transformed $k^{2}$-weighted EXAFS function. 

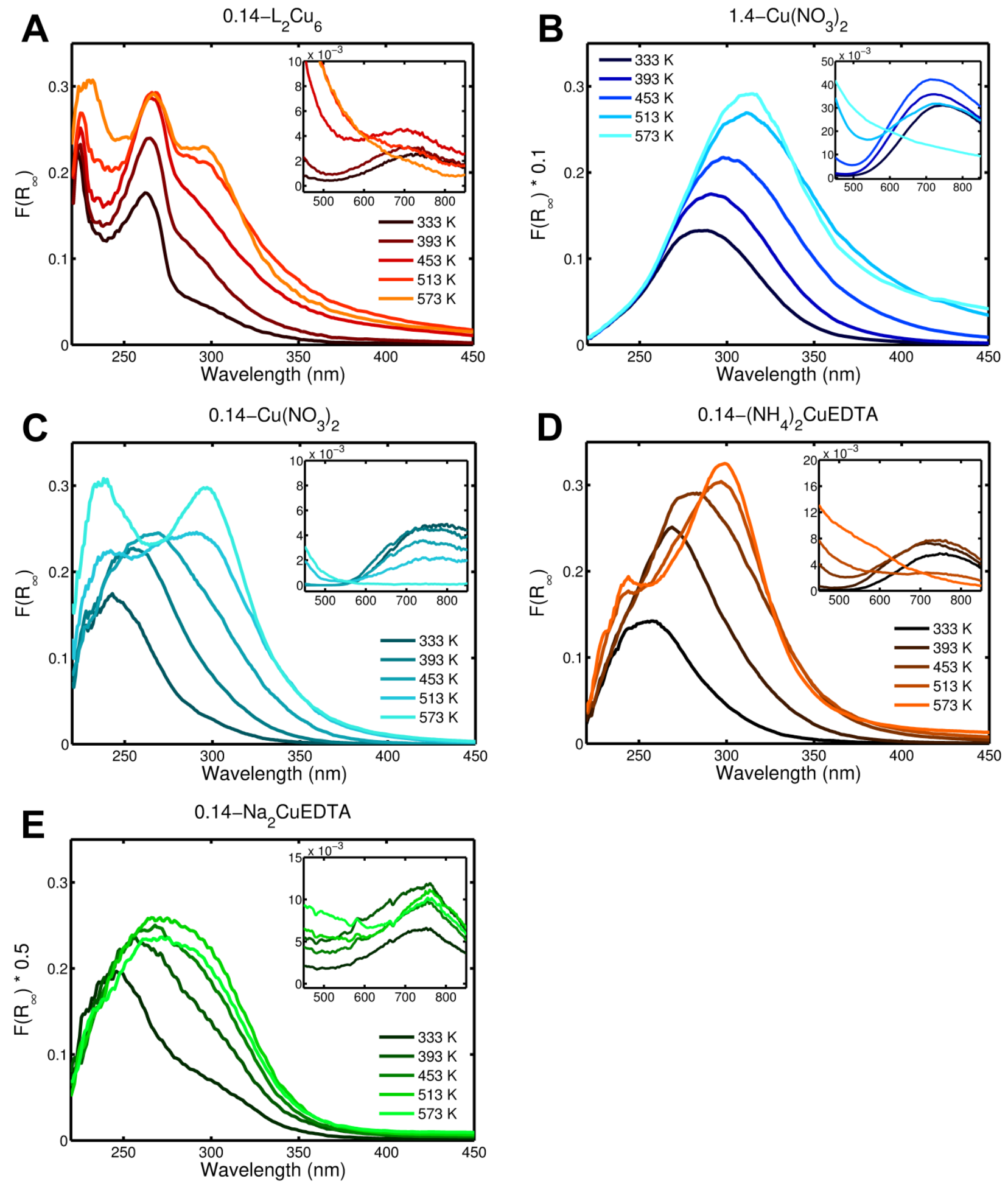

Figure 4. DRUV-vis spectra of catalysts under $3.7 \mu \mathrm{mol} / \mathrm{s}$ flow of $5 \% \mathrm{H}_{2} /$ He between $333-573 \mathrm{~K}$. Main figures show $\mathrm{LMCT}$ region while insets show $\mathrm{d}$-d transition region. A) 0.14- $\left.\left.\left.\mathrm{L}_{2} \mathrm{Cu}_{6}, \mathrm{~B}\right) 1.4-\mathrm{Cu}\left(\mathrm{NO}_{3}\right)_{2}, \mathrm{C}\right) 0.14-\mathrm{Cu}(\mathrm{NO})_{2}, \mathrm{D}\right)$ 0.14- $\left.\left(\mathrm{NH}_{4}\right)_{2} \mathrm{CuEDTA}, \mathrm{E}\right)$ 0.14- $\mathrm{Na}_{2} \mathrm{CuEDTA}$ 

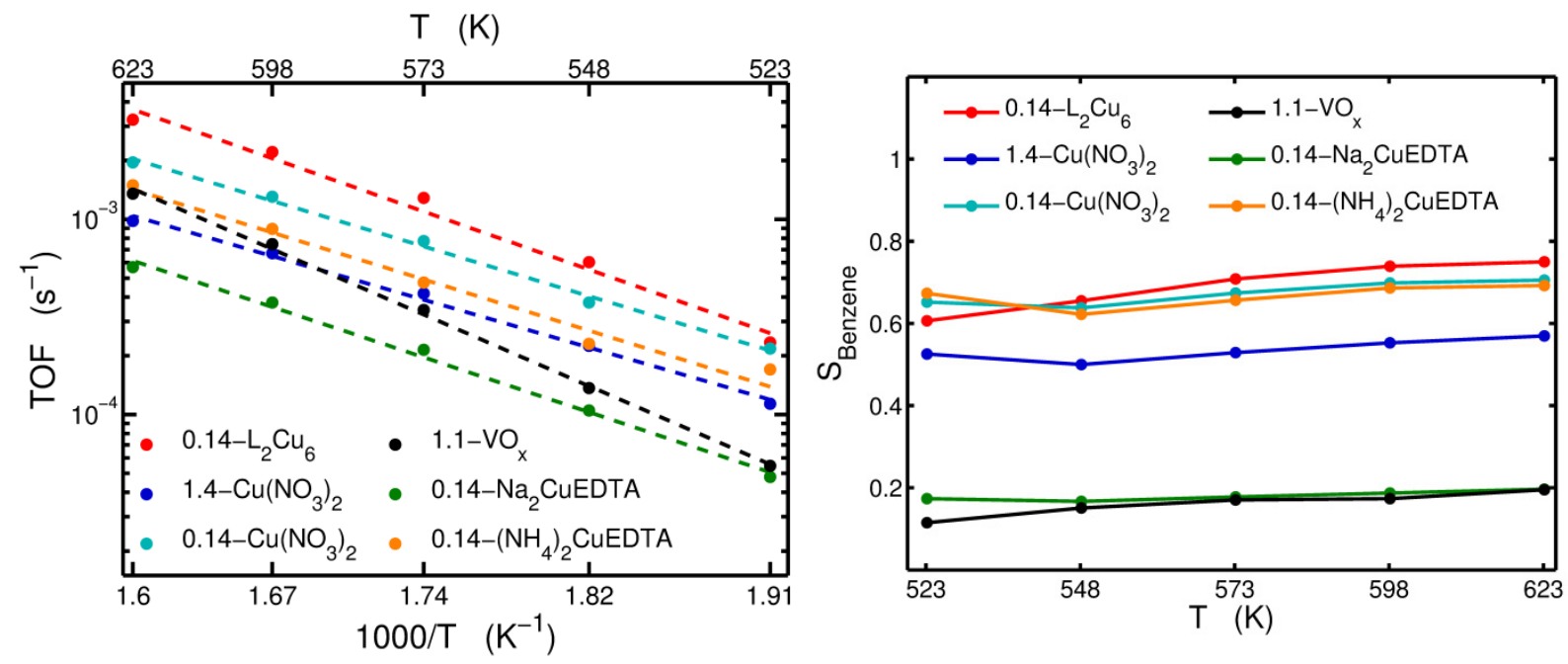

Figure 5. Temperature dependence of cyclohexane $\mathrm{ODH}(\mathrm{a})$ turnover frequency and (b) selectivity to benzene. Reaction conditions: $\mathrm{C}_{6} \mathrm{H}_{12}: \mathrm{O}_{2}: \mathrm{He}=1: 4.7: 94.3$, space velocity $=540$ mol C$_{6} \mathrm{H}_{12} /($ mol metal $* \mathrm{hr}), \mathrm{P}=1.01$ bar, $\mathrm{v}_{\text {total }}=$ $31.6 \mu \mathrm{mol} / \mathrm{s}$ gas.

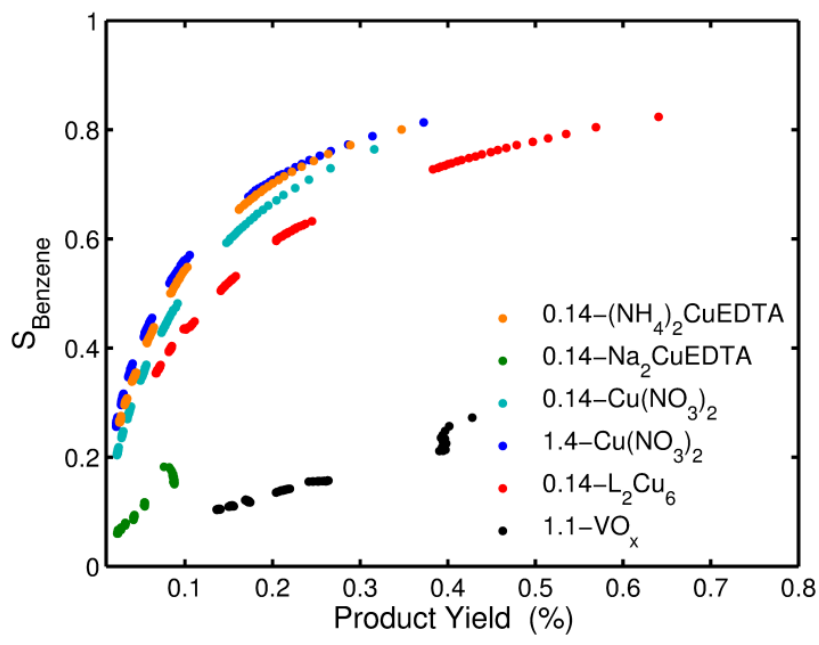

Figure 6. Selectivity to benzene as a function of product yield. Reaction conditions: $T=573 \mathrm{~K}, \mathrm{C}_{6} \mathrm{H}_{12}: \mathrm{O}_{2}: \mathrm{He}=$ 1:4.7:94.3, space velocity $=230-1770 \mathrm{~mol} \mathrm{C}_{6} \mathrm{H}_{12} /($ mol metal $* \mathrm{hr}), \mathrm{P}=1.01 \mathrm{bar}, \mathrm{v}_{\text {total }}=16.6-64.0 \mu \mathrm{mol} / \mathrm{s}$ gas. 


\title{
Cyclohexane oxidative dehydrogenation over copper oxide catalysts
}

Scott L. Nauert ${ }^{1}$,Fabian Schax ${ }^{2}$, Christian Limberg ${ }^{2}$, Justin M. Notestein ${ }^{1, *}$

\author{
${ }^{1}$ Northwestern University, Department of Chemical and Biological Engineering, \\ 2145 Sheridan Road, Technological Institute E136, Evanston, IL 60208, USA \\ ${ }^{2}$ Humboldt-Universität zu Berlin, Institut für Chemie, Berlin, Germany \\ *i-notestein@northwestern.edu \\ 847.491.5357 (phone) \\ 847.491.3728 (fax)
}

\section{Graphical Abstract}

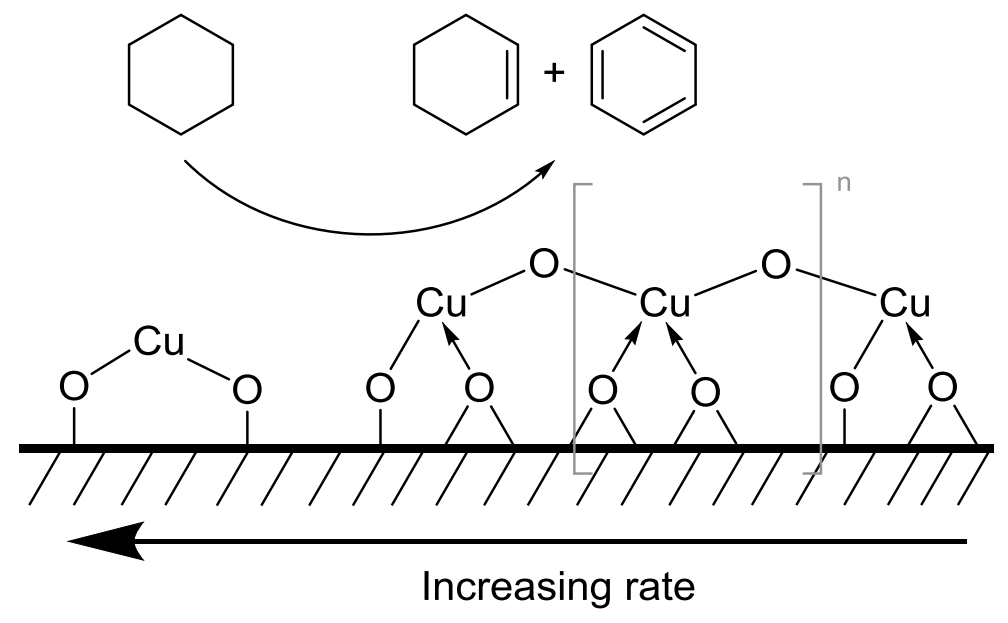

